\title{
International Changes in COVID-19 Clinical Trajectories Across 315 Hospitals and 6 Countries: Retrospective Cohort Study
}

Griffin M Weber $^{1 *}$, MD, PhD; Harrison G Zhang ${ }^{1 *}$, HSDG $^{\ddagger}$; Sehi L'Yi ${ }^{1 *}, \mathrm{PhD}$; Clara-Lea Bonzel ${ }^{1}$, MSc; Chuan Hong ${ }^{1}$, PhD; Paul Avillach ${ }^{1}$, MD, PhD; Alba Gutiérrez-Sacristán ${ }^{1}$, PhD; Nathan P Palmer ${ }^{1}$, PhD; Amelia Li Min Tan ${ }^{1}$, BSc, $\mathrm{PhD}$; Xuan Wang ${ }^{1}$, PhD; William Yuan ${ }^{1}$, PhD; Nils Gehlenborg ${ }^{1}$, PhD; Anna Alloni ${ }^{2}$, PhD; Danilo F Amendola ${ }^{3}$, MSc; Antonio Bellasi ${ }^{4}$, MD, PhD; Riccardo Bellazzi ${ }^{5}$, MS, PhD; Michele Beraghi ${ }^{6}$, MS; Mauro Bucalo ${ }^{2}$, MS; Luca Chiovato $^{7}$, MD, PhD; Kelly Cho ${ }^{8}$, PhD; Arianna Dagliati ${ }^{9}$, MS, PhD; Hossein Estiri ${ }^{10}$, PhD; Robert W Follett ${ }^{11}$, BS; Noelia García Barrio $^{12}$, MS; David A Hanauer ${ }^{13}$, MS, MD; Darren W Henderson ${ }^{14}$, BS; Yuk-Lam Ho ${ }^{8}$, MPH; John H Holmes ${ }^{15,16}$, MS, PhD; Meghan R Hutch ${ }^{17}$, BS; Ramakanth Kavuluru ${ }^{18}$, PhD; Katie Kirchoff ${ }^{19}$, MSHI; Jeffrey G Klann $^{10}$, MEng, PhD; Ashok K Krishnamurthy ${ }^{20}$, PhD; Trang T Le ${ }^{15}$, PhD; Molei Liu ${ }^{21}$, MSc; Ne Hooi Will Loh ${ }^{22}$, MBBS; Sara Lozano-Zahonero ${ }^{23}, \mathrm{PhD}$; Yuan Luo ${ }^{17}$, PhD; Sarah Maidlow ${ }^{24}$, AA; Adeline Makoudjou ${ }^{23}$, MD; Alberto Malovini $^{25}$, PhD; Marcelo Roberto Martins ${ }^{26}$, MSc; Bertrand Moal ${ }^{27}, \mathrm{MD}, \mathrm{PhD}$; Michele Morris ${ }^{28}$, BA; Danielle L Mowery ${ }^{15}$, PhD; Shawn N Murphy ${ }^{29}, \mathrm{MD}, \mathrm{PhD}$; Antoine Neuraz ${ }^{30}, \mathrm{MD}, \mathrm{PhD}$; Kee Yuan Ngiam ${ }^{31}, \mathrm{MBBS}, \mathrm{MRCS}$, MMed; Marina P Okoshi ${ }^{32}$, MD, PhD; Gilbert S Omenn ${ }^{33}$, MD, PhD; Lav P Patel ${ }^{34}$, MS; Miguel Pedrera Jiménez ${ }^{12}$, MS; Robson A Prudente ${ }^{32}$, PhD; Malarkodi Jebathilagam Samayamuthu ${ }^{28}$, MD; Fernando J Sanz Vidorreta ${ }^{11}$, BS; Emily R Schriver ${ }^{35}$, MS; Petra Schubert ${ }^{8}$, MPH; Pablo Serrano Balazote ${ }^{12}$, MS, MD; Byorn WL Tan ${ }^{36}$, MBBS; Suzana $\mathrm{E} \mathrm{Tanni}^{32}$, MD, PhD; Valentina Tibollo ${ }^{25}$, MS; Shyam Visweswaran ${ }^{28}, \mathrm{MD}, \mathrm{PhD}$; Kavishwar B Wagholikar ${ }^{10}$, MBBS, PhD; Zongqi Xia ${ }^{37}$, MD, PhD; Daniela Zöller ${ }^{23}$, PhD; The Consortium For Clinical Characterization Of COVID-19 By EHR (4CE) $)^{39}$; Isaac S Kohane ${ }^{1}$, MD, PhD; Tianxi Cai ${ }^{1 *}, \mathrm{ScD}^{\ddagger}$; Andrew M South ${ }^{38^{*}}$, MS, MD; Gabriel A Brat ${ }^{1 *}$, $\mathrm{MPH}, \mathrm{MD}$

\footnotetext{
${ }^{1}$ Department of Biomedical Informatics, Harvard Medical School, Boston, MA, United States

${ }^{2}$ BIOMERIS (BIOMedical Research Informatics Solutions), Pavia, Italy

${ }^{3}$ Clinical Research Unit, Botucatu Medical School, São Paulo State University, Botucatu, Brazil

${ }^{4}$ Division of Nephrology, Department of Medicine, Ente Ospedaliero Cantonale, Lugano, Switzerland

${ }^{5}$ Department of Electrical, Computer and Biomedical Engineering, University of Pavia, Pavia, Italy

${ }^{6}$ Information Technology Department, Azienda Socio-Sanitaria Territoriale di Pavia, Pavia, Italy

${ }^{7}$ Unit of Internal Medicine and Endocrinology, Istituti Clinici Scientifici Maugeri SpA SB IRCCS, Pavia, Italy

${ }^{8}$ Massachusetts Veterans Epidemiology Research and Information Center, Veterans Affairs Boston Healthcare System, Boston, MA, United States

${ }^{9}$ Department of Electrical Computer and Biomedical Engineering, University of Pavia, Pavia, Italy

${ }^{10}$ Department of Medicine, Massachusetts General Hospital, Boston, MA, United States

${ }^{11}$ Department of Medicine, David Geffen School of Medicine, University of California, Los Angeles, Los Angeles, CA, United States

${ }^{12}$ Health Informatics, Hospital Universitario 12 de Octubre, Madrid, Spain

${ }^{13}$ Department of Learning Health Sciences, University of Michigan Medical School, Ann Arbor, MI, United States

${ }^{14}$ Department of Biomedical Informatics, University of Kentucky, Lexington, KY, United States

${ }^{15}$ Department of Biostatistics, Epidemiology, and Informatics, University of Pennsylvania Perelman School of Medicine, Philadelphia, PA, United States

${ }^{16}$ Institute for Biomedical Informatics, University of Pennsylvania Perelman School of Medicine, Philadelphia, PA, United States

${ }^{17}$ Department of Preventive Medicine, Northwestern University, Chicago, IL, United States

${ }^{18}$ Institute for Biomedical Informatics, University of Kentucky, Lexington, KY, United States

${ }^{19}$ Medical University of South Carolina, Charleston, SC, United States

${ }^{20}$ Department of Computer Science, Renaissance Computing Institute, University of North Carolina at Chapel Hill, Chapel Hill, NC, United States

${ }^{21}$ Department of Biostatistics, Harvard T.H. Chan School of Public Health, Boston, MA, United States

${ }^{22}$ Department of Anaesthesia, National University Health System, Singapore, Singapore

${ }^{23}$ Institute of Medical Biometry and Statistics, Faculty of Medicine and Medical Center, University of Freiburg, Freiburg, Germany

${ }^{24}$ Michigan Institute for Clinical \& Health Research Informatics, University of Michigan, Ann Arbor, MI, United States
} 
${ }^{25}$ Laboratory of Informatics and Systems Engineering for Clinical Research, Istituti Clinici Scientifici Maugeri SpA SB IRCCS, Pavia, Italy

${ }^{26}$ Clinical Hospital of Botucatu Medical School, São Paulo State University, Botucatu, Brazil

${ }^{27}$ Informatique et archivistique médicales unit, Bordeaux University Hospital, Bordeaux, France

${ }^{28}$ Department of Biomedical Informatics, University of Pittsburgh, Pittsburgh, PA, United States

${ }^{29}$ Department of Neurology, Massachusetts General Hospital, Boston, MA, United States

${ }^{30}$ Department of Biomedical Informatics, Hôpital Necker-Enfants Malade, Assistance Publique Hôpitaux de Paris, University of Paris, Paris, France

${ }^{31}$ Department of Biomedical Informatics, Institute for Digital Medicine, National University Health System, Singapore, Singapore

${ }^{32}$ Internal Medicine Department, Botucatu Medical School, São Paulo State University, Botucatu, Brazil

${ }^{33}$ Department of Computational Medicine \& Bioinformatics, Internal Medicine, Human Genetics, and Public Health, University of Michigan, Ann Arbor, MI, United States

${ }^{34}$ Division of Medical Informatics, Department of Internal Medicine, University of Kansas Medical Center, Kansas City, KS, United States

${ }^{35}$ Data Analytics Center, University of Pennsylvania Health System, Philadelphia, PA, United States

${ }^{36}$ Department of Medicine, National University Health System, Singapore, Singapore

${ }^{37}$ Department of Neurology, University of Pittsburgh, Pittsburgh, PA, United States

${ }^{38}$ Section of Nephrology, Department of Pediatrics, Brenner Children's Hospital, Wake Forest School of Medicine, Winston Salem, NC, United States

${ }^{39}$ see Authors' Contributions

\$The Consortium for Clinical Characterization of COVID-19 by EHR (4CE)

* these authors contributed equally

\section{Corresponding Author:}

Tianxi Cai, ScD

Department of Biomedical Informatics

Harvard Medical School

10 Shattuck St

Boston, MA, 02115

United States

Phone: 16175488520

Email: tcai@hsph.harvard.edu

\section{Related Article:}

This is a corrected version. See correction statement in: https://www.jmir.org/2021/11/e34625

\section{Abstract}

Background: Many countries have experienced 2 predominant waves of COVID-19-related hospitalizations. Comparing the clinical trajectories of patients hospitalized in separate waves of the pandemic enables further understanding of the evolving epidemiology, pathophysiology, and health care dynamics of the COVID-19 pandemic.

Objective: In this retrospective cohort study, we analyzed electronic health record (EHR) data from patients with SARS-CoV-2 infections hospitalized in participating health care systems representing 315 hospitals across 6 countries. We compared hospitalization rates, severe COVID-19 risk, and mean laboratory values between patients hospitalized during the first and second waves of the pandemic.

Methods: Using a federated approach, each participating health care system extracted patient-level clinical data on their first and second wave cohorts and submitted aggregated data to the central site. Data quality control steps were adopted at the central site to correct for implausible values and harmonize units. Statistical analyses were performed by computing individual health care system effect sizes and synthesizing these using random effect meta-analyses to account for heterogeneity. We focused the laboratory analysis on C-reactive protein (CRP), ferritin, fibrinogen, procalcitonin, D-dimer, and creatinine based on their reported associations with severe COVID-19.

Results: Data were available for 79,613 patients, of which 32,467 were hospitalized in the first wave and 47,146 in the second wave. The prevalence of male patients and patients aged 50 to 69 years decreased significantly between the first and second waves. Patients hospitalized in the second wave had a $9.9 \%$ reduction in the risk of severe COVID-19 compared to patients hospitalized in the first wave (95\% CI 8.5\%-11.3\%). Demographic subgroup analyses indicated that patients aged 26 to 49 years and 50 to 69 years; male and female patients; and black patients had significantly lower risk for severe disease in the second wave than in the first wave. At admission, the mean values of CRP were significantly lower in the second wave than in the first wave. On the seventh hospital day, the mean values of CRP, ferritin, fibrinogen, and procalcitonin were significantly lower in the second wave than in the first wave. In general, countries exhibited variable changes in laboratory testing rates from the first to the second wave. At admission, there was a significantly higher testing rate for D-dimer in France, Germany, and Spain. 
Conclusions: Patients hospitalized in the second wave were at significantly lower risk for severe COVID-19. This corresponded to mean laboratory values in the second wave that were more likely to be in typical physiological ranges on the seventh hospital day compared to the first wave. Our federated approach demonstrated the feasibility and power of harmonizing heterogeneous EHR data from multiple international health care systems to rapidly conduct large-scale studies to characterize how COVID-19 clinical trajectories evolve.

(J Med Internet Res 2021;23(10):e31400) doi: $10.2196 / 31400$

\section{KEYWORDS}

SARS-CoV-2; electronic health records; federated study; retrospective cohort study; meta-analysis; COVID-19; severe COVID-19; laboratory trajectory

\section{Introduction}

From January 2020 to June 2021, the COVID-19 pandemic has resulted in over 170 million confirmed cases of SARS-CoV-2 infection and 3.7 million confirmed deaths worldwide [1]. Similar to previous viral pandemics, the resurgence in SARS-CoV-2 infections and subsequent hospitalizations since the first documented outbreaks have been characterized by a series of "waves." To date, there have been reports of at least two waves in numerous countries, including an initial one in the Spring of 2020 and a resurgence of cases in the Summer and Fall of 2020 [1-10]. A limited number of single-center studies have reported differences in laboratory values, demographic composition, and disease management between patients with COVID-19 admitted in the first and second waves $[6,8,11,12]$. Thus, there is substantial interest in comparing the clinical trajectories of patients with SARS-CoV-2 who were hospitalized across different waves of the pandemic to better understand the rapidly evolving epidemiology, pathophysiology, and health care dynamics of the COVID-19 pandemic. This may further inform health care workers, policymakers, and public health experts on how to anticipate potential additional waves due to SARS-CoV-2 variants [13].

Single-center studies are limited in scope, power, and generalizability, and there is a need for robust multicenter analyses using multinational cohorts that compare first and second wave patient characteristics. The goal of this study was to use a federated electronic health record (EHR)-based approach to examine international temporal trends in the clinical trajectories of patients hospitalized with SARS-CoV-2 across 6 countries obtained from contributing health care systems in the Consortium for Clinical Characterization of COVID-19 by EHR (4CE) [14], an international research collaborative of more than 300 hospitals across 7 countries that collects patient-level EHR data to study the epidemiology and clinical course of COVID-19. We collected data from 26 participating international health care systems covering 79,613 hospitalized patients with SARS-CoV-2 to study changes in (1) hospitalization rates across calendar time; (2) risk of developing severe COVID-19; and (3) mean laboratory values and laboratory testing rates between the first and second waves. We stratified severity risk analyses by country and demographic subgroups.

\section{Methods}

\section{Description of the Federated Approach: Participating Health Care Systems, Local Data Collection, and Central Data Aggregation}

Our analyses were performed on EHR data collected from 315 hospitals (affiliated with 26 regional health care systems) across the following 6 countries: Brazil, France, Germany, Italy, Spain, and the United States $[14,15]$. In the United States, we grouped the 170 Veterans Affairs (VA) hospitals into 5 regional health care systems [16]. See Table 1 for details about participating health care systems and Figure 1 for a map of participating health care systems. 
Table 1. Participating health care systems, metadata on the number of hospitals and beds, and hospitalization date used to define the first and second wave cohorts.

\begin{tabular}{|c|c|c|c|c|c|c|c|c|}
\hline Health care system & Country & $\begin{array}{l}\text { Hospitals, } \\
\mathrm{n}\end{array}$ & Beds, $\mathrm{n}$ & $\begin{array}{l}\text { Inpatient dis- } \\
\text { charges/year, } \\
\mathrm{n}\end{array}$ & $\begin{array}{l}\text { First wave date } \\
\text { range }\end{array}$ & $\begin{array}{l}\text { Second wave date } \\
\text { range }\end{array}$ & $\begin{array}{l}\text { First wave } \\
\text { sample size, } \\
\mathrm{n}\end{array}$ & $\begin{array}{l}\text { Second wave } \\
\text { sample size, } \\
\mathrm{n}\end{array}$ \\
\hline $\begin{array}{l}\text { Assistance Publique - } \\
\text { Hôpitaux de Paris }\end{array}$ & France & 39 & 20,098 & $1,375,538$ & $\begin{array}{l}\text { January } 29,2020 \text {, } \\
\text { to August } 10, \\
2020\end{array}$ & $\begin{array}{l}\text { August } 11,2020 \text {, } \\
\text { to November 06, } \\
2020\end{array}$ & 9827 & 4584 \\
\hline $\begin{array}{l}\text { Azienda Socio-Sanitaria } \\
\text { Territoriale della provincia } \\
\text { di Pavia }\end{array}$ & Italy & 7 & 958 & 29,103 & $\begin{array}{l}\text { February } 28, \\
2020 \text {, to April } 30, \\
2020\end{array}$ & $\begin{array}{l}\text { May } 01,2020, \text { to } \\
\text { February } 15,2021\end{array}$ & 945 & 1543 \\
\hline $\begin{array}{l}\text { Beth Israel Deaconess } \\
\text { Medical Center }\end{array}$ & $\begin{array}{l}\text { United } \\
\text { States }\end{array}$ & 1 & 673 & 40,752 & $\begin{array}{l}\text { March 23, 2020, } \\
\text { to September 02, } \\
2020\end{array}$ & $\begin{array}{l}\text { September } 03 \text {, } \\
2020 \text {, to February } \\
22,2021\end{array}$ & 685 & 585 \\
\hline $\begin{array}{l}\text { Bordeaux University Hos- } \\
\text { pital }\end{array}$ & France & 3 & 2676 & 130,033 & $\begin{array}{l}\text { January } 23,2020 \text {, } \\
\text { to July } 31,2020\end{array}$ & $\begin{array}{l}\text { August } 01,2020 \text {, } \\
\text { to November } 07, \\
2020\end{array}$ & 331 & 439 \\
\hline $\begin{array}{l}\text { Hospital Universitario } 12 \\
\text { de Octubre }\end{array}$ & Spain & 1 & 1256 & 45,035 & $\begin{array}{l}\text { March 01, 2020, } \\
\text { to July 20, } 2020\end{array}$ & $\begin{array}{l}\text { July } 21,2020, \text { to } \\
\text { February } 28,2021\end{array}$ & 2369 & 3730 \\
\hline $\begin{array}{l}\text { Azienda Socio-Sanitaria } \\
\text { Territoriale Papa Giovanni } \\
\text { XXIII Bergamo }\end{array}$ & Italy & 1 & 1080 & 45,000 & $\begin{array}{l}\text { February 25, } \\
2020, \text { to May 21, } \\
2020\end{array}$ & $\begin{array}{l}\text { May 22, 2020, to } \\
\text { November 13, } \\
2020\end{array}$ & 1533 & 371 \\
\hline $\begin{array}{l}\text { Istituto Clinico Scientifico } \\
\text { Maugeri Pavia Hospital }\end{array}$ & Italy & 1 & 426 & 8616 & $\begin{array}{l}\text { February } 29, \\
2020, \text { to May } 08 \\
2020\end{array}$ & $\begin{array}{l}\text { May 09, 2020, to } \\
\text { November } 16, \\
2020\end{array}$ & 113 & 58 \\
\hline $\begin{array}{l}\text { Istituto Clinico Scientifico } \\
\text { Maugeri } \\
\text { Milano Hospital }\end{array}$ & Italy & 1 & 200 & 2432 & $\begin{array}{l}\text { February } 21, \\
2020, \text { to May } 08, \\
2020\end{array}$ & $\begin{array}{l}\text { May } 09,2020 \text {, to } \\
\text { November } 16, \\
2020\end{array}$ & 38 & 119 \\
\hline $\begin{array}{l}\text { Istituto Clinico Scientifico } \\
\text { Maugeri Lumezzane/Bres- } \\
\text { cia Hospitals }\end{array}$ & Italy & 1 & 149 & 1296 & $\begin{array}{l}\text { March } 11,2020 \text {, } \\
\text { to May 08, 2020 }\end{array}$ & $\begin{array}{l}\text { May } 09,2020 \text {, to } \\
\text { November } 16 \text {, } \\
2020\end{array}$ & 111 & 21 \\
\hline $\begin{array}{l}\text { Mass General Brigham } \\
\text { (Partners Healthcare) }\end{array}$ & $\begin{array}{l}\text { United } \\
\text { States }\end{array}$ & 10 & 3418 & 163,521 & $\begin{array}{l}\text { March } 11,2020, \\
\text { to July } 31,2020\end{array}$ & $\begin{array}{l}\text { August } 01,2020 \text {, } \\
\text { to February } 28 \text {, } \\
2021\end{array}$ & 2736 & 1735 \\
\hline $\begin{array}{l}\text { Medical University of } \\
\text { South Carolina }\end{array}$ & $\begin{array}{l}\text { United } \\
\text { States }\end{array}$ & 8 & 1600 & 55,664 & $\begin{array}{l}\text { March } 12,2020, \\
\text { to May 25, } 2020\end{array}$ & $\begin{array}{l}\text { May 26, 2020, to } \\
\text { November } 15, \\
2020\end{array}$ & 127 & 1482 \\
\hline Northwestern University & $\begin{array}{l}\text { United } \\
\text { States }\end{array}$ & 10 & 2234 & 103,279 & $\begin{array}{l}\text { March } 05,2020 \text {, } \\
\text { to July } 31,2020\end{array}$ & $\begin{array}{l}\text { August } 01,2020 \text {, } \\
\text { to December 31, } \\
2020\end{array}$ & 2313 & 3567 \\
\hline Policlinico di Milano & Italy & 1 & 900 & 40,000 & $\begin{array}{l}\text { February 25, } \\
2020, \text { to August } \\
01,2020\end{array}$ & $\begin{array}{l}\text { August } 02,2020 \text {, } \\
\text { to November } 13 \text {, } \\
2020\end{array}$ & 612 & 304 \\
\hline $\begin{array}{l}\text { Medical Center, University } \\
\text { of Freiburg }\end{array}$ & Germany & 1 & 1660 & 71,500 & $\begin{array}{l}\text { March } 13,2020, \\
\text { to July } 31,2020\end{array}$ & $\begin{array}{l}\text { August } 01,2020 \text {, } \\
\text { to February } 28, \\
2021\end{array}$ & 186 & 490 \\
\hline $\begin{array}{l}\text { University of California, } \\
\text { LA }\end{array}$ & $\begin{array}{l}\text { United } \\
\text { States }\end{array}$ & 2 & 786 & 40,526 & $\begin{array}{l}\text { March 10, 2020, } \\
\text { to August 03, } \\
2020\end{array}$ & $\begin{array}{l}\text { August } 04,2020 \text {, } \\
\text { to November } 13 \text {, } \\
2020\end{array}$ & 425 & 151 \\
\hline University of Kentucky & $\begin{array}{l}\text { United } \\
\text { States }\end{array}$ & 3 & 881 & 45,714 & $\begin{array}{l}\text { March } 18,2020, \\
\text { to July } 07,2020\end{array}$ & $\begin{array}{l}\text { July } 08,2020 \text {, to } \\
\text { November } 06 \text {, } \\
2020\end{array}$ & 113 & 352 \\
\hline University of Michigan & $\begin{array}{l}\text { United } \\
\text { States }\end{array}$ & 3 & 1000 & 49,008 & $\begin{array}{l}\text { March 09, 2020, } \\
\text { to July } 31,2020\end{array}$ & $\begin{array}{l}\text { August } 01,2020 \text {, } \\
\text { to February } 28 \text {, } \\
2021\end{array}$ & 745 & 1619 \\
\hline $\begin{array}{l}\text { University Medicine } \\
\text { Mannheim }\end{array}$ & Germany & 1 & 1352 & 50,748 & $\begin{array}{l}\text { March 18, 2020, } \\
\text { to August 03, } \\
2020\end{array}$ & $\begin{array}{l}\text { August } 04,2020 \text {, } \\
\text { to January } 23, \\
2021\end{array}$ & 81 & 497 \\
\hline
\end{tabular}




\begin{tabular}{|c|c|c|c|c|c|c|c|c|}
\hline Health care system & Country & $\begin{array}{l}\text { Hospitals, } \\
\mathrm{n}\end{array}$ & Beds, $\mathrm{n}$ & $\begin{array}{l}\text { Inpatient dis- } \\
\text { charges/year, } \\
\mathrm{n}\end{array}$ & $\begin{array}{l}\text { First wave date } \\
\text { range }\end{array}$ & $\begin{array}{l}\text { Second wave date } \\
\text { range }\end{array}$ & $\begin{array}{l}\text { First wave } \\
\text { sample size, } \\
\mathrm{n}\end{array}$ & $\begin{array}{l}\text { Second wave } \\
\text { sample size, } \\
\text { n }\end{array}$ \\
\hline $\begin{array}{l}\text { University of North Caroli- } \\
\text { na at Chapel Hill }\end{array}$ & $\begin{array}{l}\text { United } \\
\text { States }\end{array}$ & 11 & 3095 & 52,000 & $\begin{array}{l}\text { March } 14,2020 \text {, } \\
\text { to June } 05,2020\end{array}$ & $\begin{array}{l}\text { June } 06,2020 \text {, to } \\
\text { October } 30,2020\end{array}$ & 458 & 1525 \\
\hline $\begin{array}{l}\text { Universidade Estadual } \\
\text { Julio de Mesquita Filho }\end{array}$ & Brazil & 1 & 490 & 28,167 & $\begin{array}{l}\text { April } 01,2020 \text {, to } \\
\text { July } 31,2020\end{array}$ & $\begin{array}{l}\text { August } 01,2020 \text {, } \\
\text { to February } 28 \text {, } \\
2021\end{array}$ & 171 & 425 \\
\hline University of Pittsburgh & $\begin{array}{l}\text { United } \\
\text { States }\end{array}$ & 39 & 8085 & 369,300 & $\begin{array}{l}\text { March } 13,2020 \text {, } \\
\text { to July } 31,2020\end{array}$ & $\begin{array}{l}\text { August } 01,2020 \text {, } \\
\text { to February } 28 \text {, } \\
2021\end{array}$ & 685 & 5021 \\
\hline $\begin{array}{l}\text { Veteran Affairs North At- } \\
\text { lantic }\end{array}$ & $\begin{array}{l}\text { United } \\
\text { States }\end{array}$ & 49 & 3594 & 151,075 & $\begin{array}{l}\text { March 01, 2020, } \\
\text { to July } 31,2020\end{array}$ & $\begin{array}{l}\text { August } 01,2020 \text {, } \\
\text { to February } 04 \text {, } \\
2021\end{array}$ & 1949 & 2984 \\
\hline Veteran Affairs Southwest & $\begin{array}{l}\text { United } \\
\text { States }\end{array}$ & 29 & 3115 & 156,315 & $\begin{array}{l}\text { March 01, 2020, } \\
\text { to July } 31,2020\end{array}$ & $\begin{array}{l}\text { August } 01,2020 \text {, } \\
\text { to February } 04 \text {, } \\
2021\end{array}$ & 1679 & 4071 \\
\hline Veteran Affairs Midwest & $\begin{array}{l}\text { United } \\
\text { States }\end{array}$ & 39 & 2686 & 145,468 & $\begin{array}{l}\text { March 01, 2020, } \\
\text { to July } 31,2020\end{array}$ & $\begin{array}{l}\text { August } 01,2020 \text {, } \\
\text { to February } 04 \text {, } \\
2021\end{array}$ & 1544 & 4617 \\
\hline $\begin{array}{l}\text { Veteran Affairs Continen- } \\
\text { tal }\end{array}$ & $\begin{array}{l}\text { United } \\
\text { States }\end{array}$ & 24 & 2110 & 113,260 & $\begin{array}{l}\text { March 01, 2020, } \\
\text { to July } 31,2020\end{array}$ & $\begin{array}{l}\text { August } 01,2020 \text {, } \\
\text { to February } 04 \text {, } \\
2021\end{array}$ & 1497 & 3495 \\
\hline Veteran Affairs Pacific & $\begin{array}{l}\text { United } \\
\text { States }\end{array}$ & 29 & 2296 & 114,569 & $\begin{array}{l}\text { March 01, 2020, } \\
\text { to July } 31,2020\end{array}$ & $\begin{array}{l}\text { August } 01,2020 \text {, } \\
\text { to February } 04 \text {, } \\
2021\end{array}$ & 1194 & 3361 \\
\hline Total & $\mathrm{N} / \mathrm{A}^{\mathrm{a}}$ & 315 & 66,818 & $3,427,919$ & N/A & N/A & 32,467 & 47,146 \\
\hline
\end{tabular}

${ }^{\mathrm{a} N} / \mathrm{A}$ : not applicable. 
Figure 1. (A) World map with health care systems. (B) Schematic of the federated electronic health record (EHR)-based study involving health care systems from 6 countries. 4CE: Consortium for Clinical Characterization of COVID-19 by EHR; ICD: International Classification of Diseases.

\section{A}
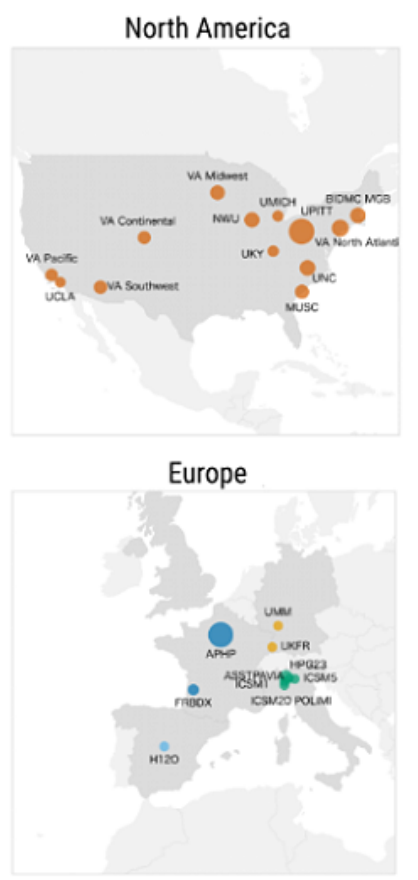

South America

\section{B}

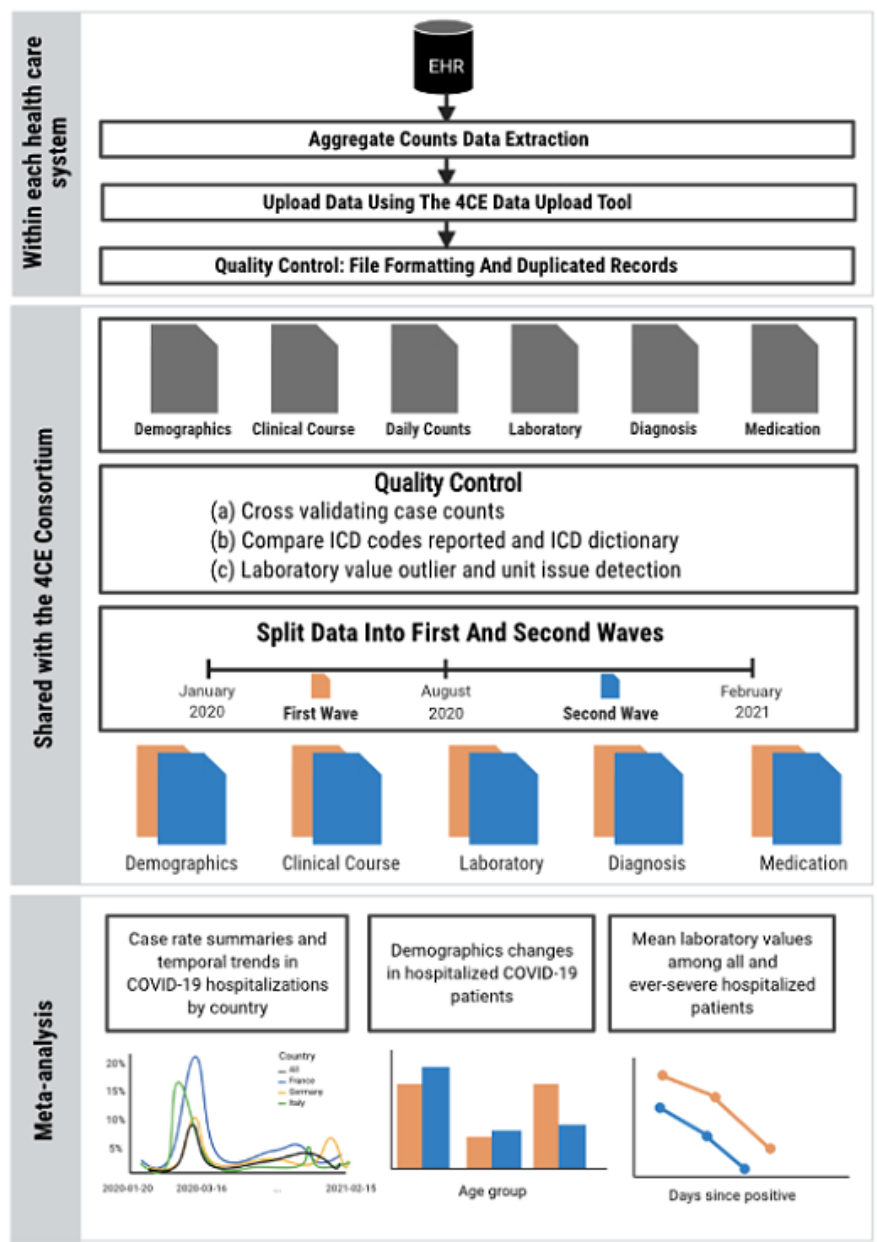

Similar to our previous $4 \mathrm{CE}$ studies, we distributed a SQL database script to each of the contributing health care systems, which they ran on their patient-level EHR data to generate aggregate counts and statistics about their patient cohorts after gaining institutional review board approval $[14,15,17]$. Health care systems then uploaded their aggregate data via a central 4CE data upload tool. Aggregate data included hospital admission summaries over calendar time; dates of positive SARS-CoV-2 reverse transcription polymerase chain reaction tests; demographic counts for age, sex, and race groups; and daily trajectories of laboratory test values. Race data were only reported in participating health care systems from the United States and only included categories for black and white patients given the considerable heterogeneity present in race coding systems across health care system EHRs. A schematic of our workflow is presented in Figure 1, and further details of collected data are reported in Multimedia Appendix 1.

In order to ensure high-quality EHR data across health care systems and countries, extensive data quality control was performed. When sites uploaded the data using the 4CE data upload tool, an initial online quality control verified that all comma separated value (CSV) files were under the standard format, which included verification of the file and column names, column orders, data types, code values and ranges, and the absence of duplicated records. This step was crucial in ensuring proper downstream statistical analysis. At the central site, additional quality control steps were completed on all submitted data. These steps included cross-validating the consistency of the total case counts, checking that there are no negative values in patient counts, and verifying that no data types were missing. We also checked for consistency between the 3-digit International Classification of Diseases (ICD) codes and the ICD dictionary. To assess the general consistency of the laboratory data from each site with data observed from all health care systems and to detect outliers, we plotted laboratory values across time with all sites overlaid on each other. Using these plots, we were also able to check if certain laboratory values from specific health care systems were systematically lower or higher than for other sites, which usually indicated unit errors. If a health care system presented any quality control 
issues, the central site directly contacted its corresponding informaticians to resolve them.

\section{Cohort Identification}

Our study included all patients hospitalized up to February 28, 2021, at participating 4CE health care systems with an admission date between 7 days before to 14 days after the date of the first positive SARS-CoV-2 reverse transcription polymerase chain reaction test result. We chose this time window in an effort to mitigate selection bias by identifying hospitalized patients who may have tested positive for SARS-CoV-2 before or after being admitted to a hospital. We further defined the first admission date within this -7 to +14 -day time window as the index date, and "days since admission" and "hospital day" are referenced to this index date. EHR data were available for 79,613 patients.

We partitioned patients into first- and second-wave cohorts according to their index date. Although different regions had slightly varying temporal trajectories in COVID-19-related hospitalizations, our data indicated 2 predominant waves of hospitalizations, which we used to partition patients as follows: a first wave from January 1 to July 31, 2020, and a second wave from August 1, 2020, to February 28, 2021. Relatively few admissions occurred between July and August 2020 across all health care systems. Table 1 defines health care system-specific hospitalization date criteria for the first and second waves.

We further categorized patients as "ever-severe" using the validated 4CE COVID-19 severity algorithm that allows us to determine whether patients, at any time during their hospitalization, progressed to severe disease, regardless of their recovery from COVID-19 [18]. The algorithm leverages a set of EHR data elements to define severe COVID-19 including (1) laboratory tests for partial pressure of carbon dioxide or partial pressure of oxygen; (2) ordered medications for sedatives and anesthetics; (3) diagnosis codes for acute respiratory distress syndrome or ventilator-associated pneumonia; and (4) procedures such as endotracheal tube insertion and invasive mechanical ventilation [18].

\section{Statistical Analysis}

Centralized random effect meta-analyses were performed to summarize individual health care system effect sizes. To account for heterogeneity between health care systems, we harmonized effect sizes using DerSimonian and Laird random effect meta-analysis [19]. Weights assigned to health care system effect sizes during meta-analysis were kept constant between corresponding first and second cohort analyses to facilitate effective comparisons between waves. All statistical analyses were performed using $\mathrm{R}$ software version 4.0.2 ( $\mathrm{R}$ Foundation for Statistical Computing).

We estimated the intensity rate of hospitalizations over time within each participating health care system and averaged at the country level. Within each health care system, the intensity rate for a given calendar date was estimated as the proportion of patients in the cohort who were hospitalized on that date. We further summarized the prevalence of demographic subgroups in the first and second waves. We excluded the VA health care systems only when estimating the prevalence of demographic subgroups in our cohort due to their unique demographic profiles [20]. We report the prevalence of demographic subgroups including the VA health care systems in Multimedia Appendix 2.

We then estimated the absolute risk of severe COVID-19 in the first and second waves and the relative risk (RR) of severe COVID-19 in the second wave compared with the first wave. Within each health care system and over a set time period of interest, the absolute risk was estimated as the proportion of patients who ever developed severe disease among all patients in the corresponding cohort. We stratified these analyses by country and demographic subgroups. Analyses of absolute risk and RR for severe COVID-19 included all participating health care systems.

We then compared standardized mean laboratory test values stratified by disease severity at days 0,1 , and 7 to investigate changes in laboratory trajectories between the 2 waves. We focused on the following 6 blood laboratory values associated with worse outcomes and severe disease in patients with COVID-19: C-reactive protein (CRP), ferritin, fibrinogen, procalcitonin, D-dimer, and creatinine [21-28]. To facilitate effective comparisons, we defined standardized laboratory values as relative to each laboratory test's harmonized value on the index date in the first wave. We also summarized the proportion of all and ever-severe patients having each laboratory test at days 0 to 14 stratified by country to examine any changes in clinical practice regarding laboratory testing.

\section{Ethics Approval}

All study sites were responsible for and obtained ethics approval, as needed, from the appropriate ethics committee at their institutions.

\section{Data Sharing Statement}

Deidentified aggregate data were provided by sites for this study. The 4CE provides samples of deidentified data collected by the consortium and some corresponding visualizations on the consortium website [29].

\section{Results}

\section{Characteristics of the Study Population and Trends in Hospitalization}

In the study population of 79,613 hospitalized patients with SARS-CoV-2, 32,467 were hospitalized during the first wave and 47,146 were hospitalized during the second wave. In this cohort, the United States represented the country with the most hospitalizations. As seen in Figure 2B, hospitalization rates generally peaked in March-April of 2020 and again in the final months of 2020 across all 6 countries. 
Figure 2. (A) Total hospitalizations in the cohort between the first and second waves. (B) The intensity rate of hospitalizations over time by country.

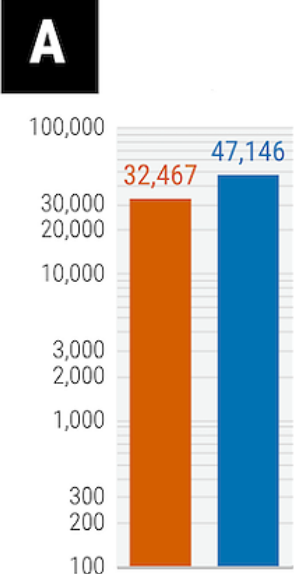

ALL

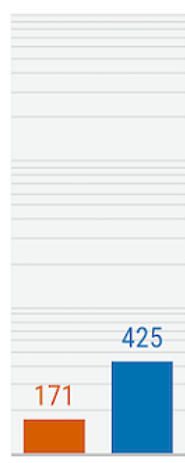

BRAZIL

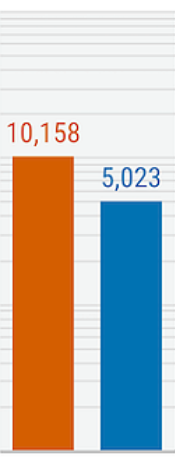

FRANCE

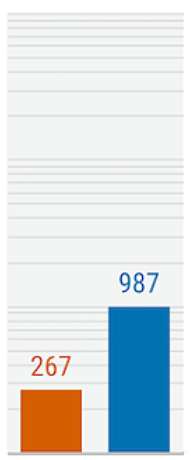

GERMANY

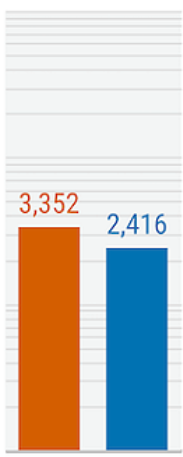

ITALY

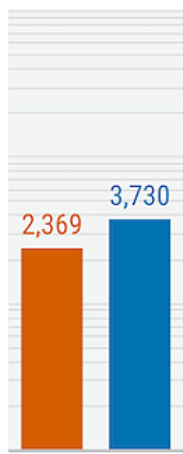

SPAIN

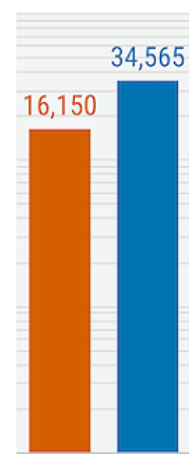

USA

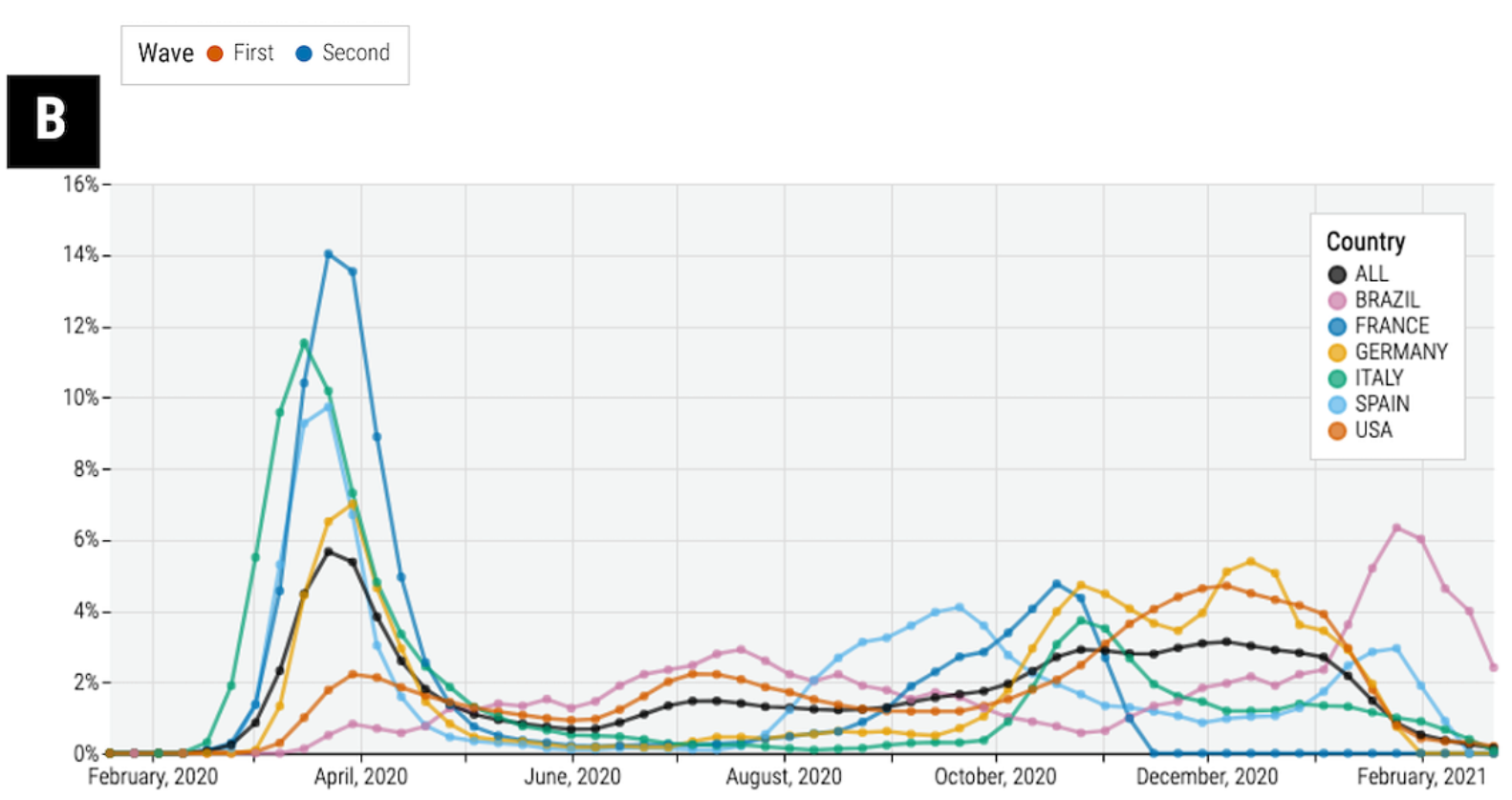

We report the prevalence of demographic subgroups in Figure 3. Overall, there was a higher prevalence of male and older age patients in both waves. The prevalence of patients aged 50 to 69 years decreased significantly from the first wave $(37.1 \%$, $95 \%$ CI $35.0 \%-39.3 \%)$ to the second wave $(32.3 \%, 95 \% \mathrm{CI}$ $30.5 \%-34.2 \%)$. The prevalence of male patients also decreased from the first wave $(55.3 \%, 95 \%$ CI $53.1 \%-57.5 \%)$ to the second wave $(50.9 \%, 95 \%$ CI $49.1 \%-52.6 \%)$. There were no statistically significant changes in the prevalence of other age or sex groups for the entire cohort. At the country level, we observed that in Spain, the prevalence of patients aged 26 to 49 years increased significantly from $21.0 \%$ (95\% CI $19.4 \%-22.7 \%$ ) in the first wave to $24.3 \%$ (95\% CI $23.0 \%-25.7 \%$ ) in the second wave, while the prevalence of patients aged 70 to 79 years decreased significantly from $16.8 \%$ (95\% CI $15.4 \%-18.4 \%$ ) in the first wave to $14.1 \%$ (95\% CI $13.0 \%-15.3 \%$ ) in the second wave. In the United States, the prevalence of white patients increased (first wave: $46.3 \%, 95 \%$ CI $36.3 \%-56.6 \%$ vs second wave: $60.2 \%, 95 \%$ CI $48.1 \%-71.1 \%$ ), while the prevalence of black patients decreased (first wave: $29.7 \%$, 95\% CI 20.0\%-41.8\% vs second wave: $19.4 \%, 95 \%$ CI $13.3 \%-27.5 \%$ ), although both results did not reach statistical significance. 
Figure 3. (A) Prevalence of demographic subgroups in the first and second waves for the entire cohort and estimated absolute risk for severe COVID-19 by demographic subgroup. (B) Country-level demographics of all patients by wave. Error bars indicate $95 \%$ CIs. *Significant difference by nonoverlapping $95 \%$ CIs.

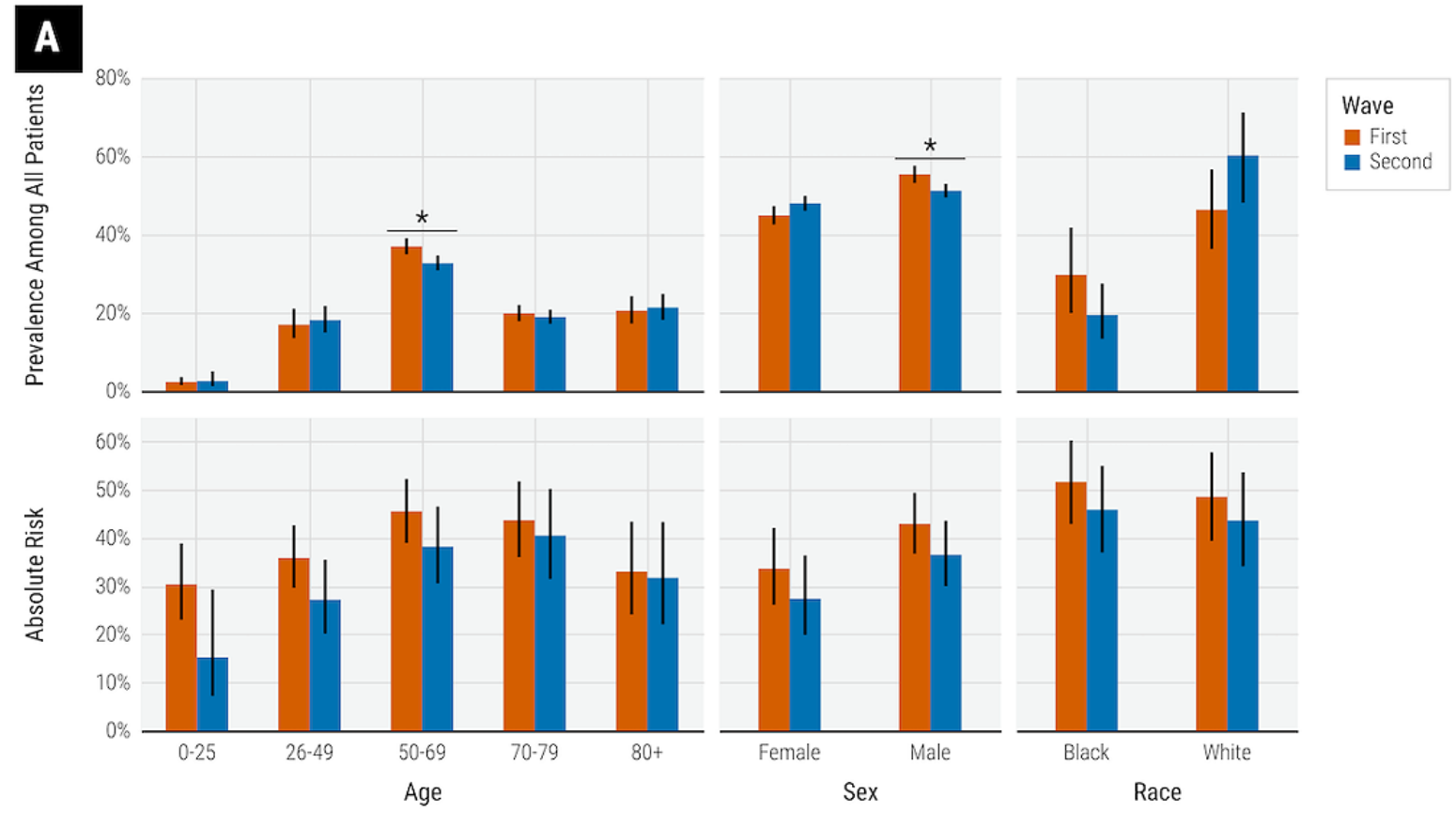

\section{B}
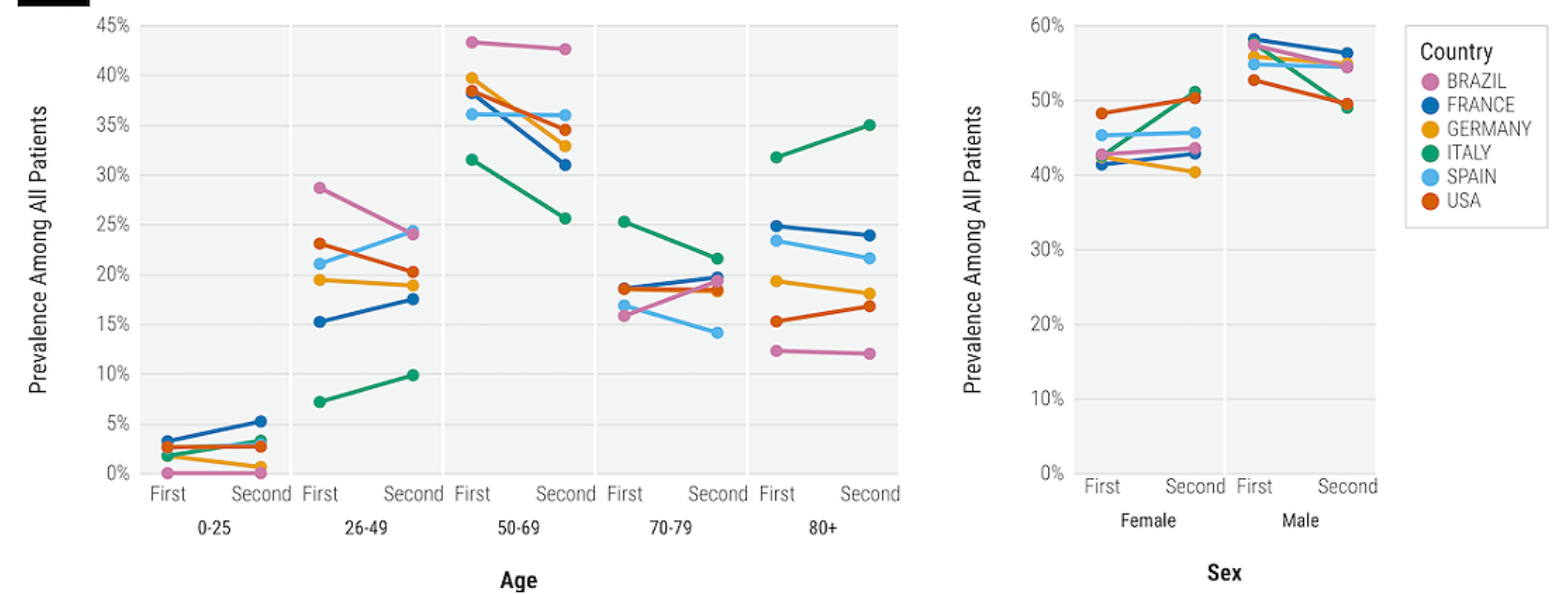

\section{Risk of Severe Disease in the First and Second Waves}

We report the absolute risk and RR for severe COVID-19 stratified by country in Figure 4. The absolute risk of severe disease was 0.40 (95\% CI 0.34-0.48) in the first wave and 0.33 (95\% CI 0.25-0.43) in the second wave. The absolute risk for severe disease varied significantly across countries in both waves (first wave vs second wave) as follows: Brazil, 30.1\% vs $8.7 \%$; France, $66.7 \%$ vs $60.1 \%$; Germany, $33.3 \%$ vs $25.8 \%$; Italy, $12.6 \%$ vs $6.5 \%$; Spain, $38.3 \%$ vs $44.5 \%$; United States,
$49.4 \%$ vs $44.8 \%$. The RR of severe disease in the second wave compared to the first wave was more comparable across Brazil (RR 0.29 , 95\% CI 0.20-0.42), France (RR 0.90, 95\% CI 0.87-0.92), and the United States (RR 0.88, 95\% CI 0.87-0.90). The observed RR was 0.78 (95\% CI 0.52-1.17) in Germany and 0.53 (95\% CI 0.27-1.04) in Italy, but the reduction in risk was not statistically significant. In contrast, patients in Spain (RR $1.16,95 \%$ CI 1.09-1.24) had a slightly higher risk of severe COVID-19 in the second wave than in the first wave. 
Figure 4. (A) Absolute risk for severe COVID-19 in the first and second waves. (B) Relative risk of severe COVID-19 in the second compared to the first wave stratified by country. Error bars indicate $95 \%$ CIs.

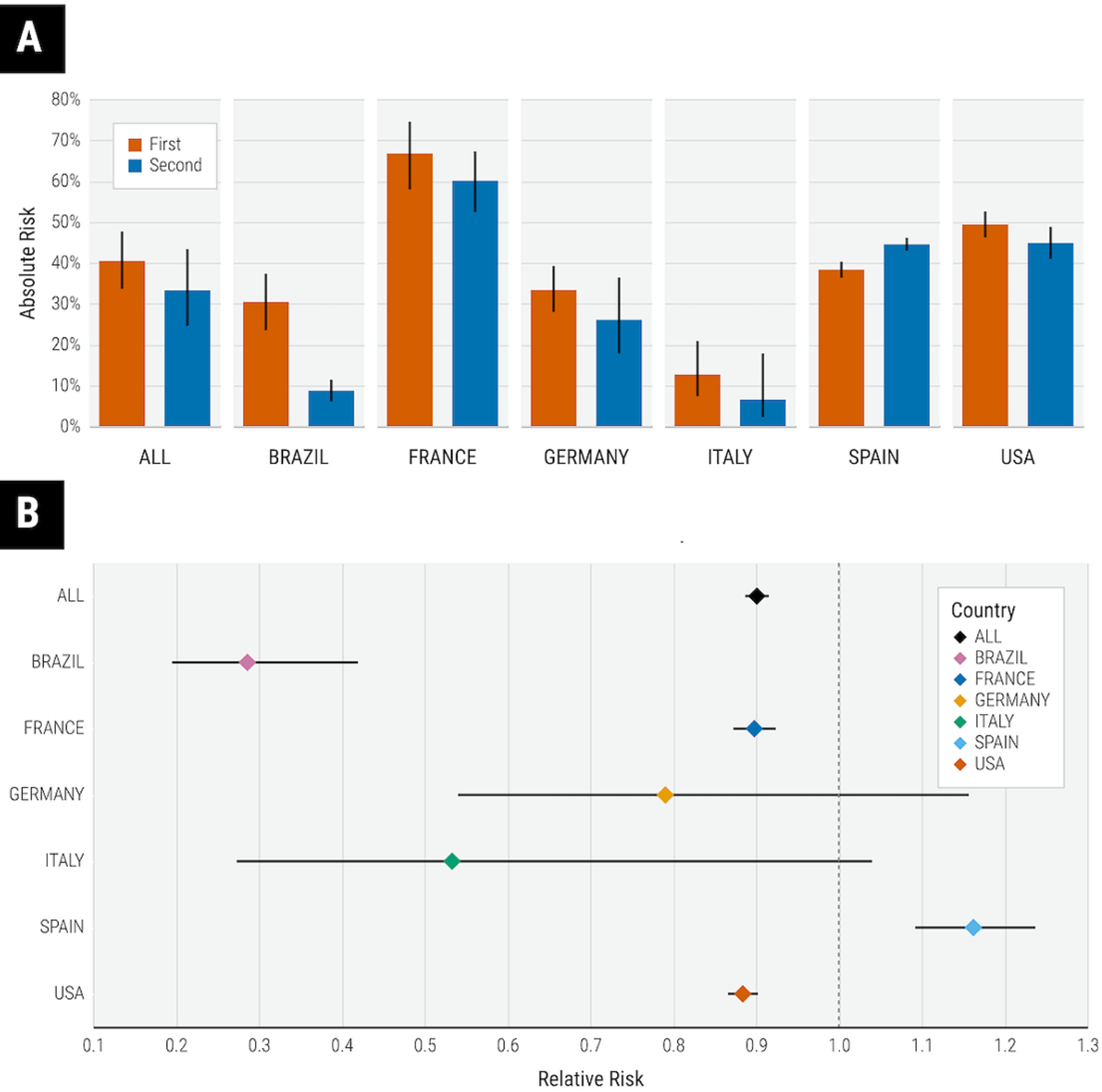

We report the absolute risk and RR for severe COVID-19 stratified by demographic subgroups in Figure 3A and Table 2, respectively. Across demographic subgroups in the second wave, there were significant reductions in risk among patients aged 26 to 49 years and 50 to 69 years; male and female patients; and black patients. RR effect sizes were generally comparable between sexes and between races. The reduction in risk in the second wave was slightly greater for younger age groups than for older age groups. 
Table 2. Relative risk of severe disease in the second wave compared to the first wave stratified by demographic subgroups and by country.

\begin{tabular}{|c|c|c|c|c|c|c|c|}
\hline $\begin{array}{l}\text { Demograph- } \\
\text { ic group }\end{array}$ & $\begin{array}{l}\text { All countries, } \\
\operatorname{RR}^{\mathrm{a}}(95 \% \mathrm{CI})\end{array}$ & $\begin{array}{l}\text { Brazil, RR (95\% } \\
\text { CI) }\end{array}$ & $\begin{array}{l}\text { France, RR }(95 \% \\
\text { CI })\end{array}$ & $\begin{array}{l}\text { Germany, RR } \\
(95 \% \mathrm{CI})\end{array}$ & $\begin{array}{l}\text { Italy, RR }(95 \% \\
\text { CI) }\end{array}$ & $\begin{array}{l}\text { Spain, RR }(95 \% \\
\text { CI })\end{array}$ & $\begin{array}{l}\text { United States, RR } \\
(95 \% \text { CI })\end{array}$ \\
\hline \multicolumn{8}{|l|}{ Age (years) } \\
\hline $0-25$ & $0.75(0.56-1.02)$ & $\mathrm{N} / \mathrm{A}^{\mathrm{b}}$ & $1.50(1.08-2.09)^{\mathrm{c}}$ & N/A & N/A & $\mathrm{N} / \mathrm{A}$ & $0.80(0.59-1.09)$ \\
\hline $26-49$ & $0.77(0.63-0.94)^{\mathrm{c}}$ & $0.31(0.16-0.61)^{\mathrm{c}}$ & $0.86(0.57-1.31)$ & $1.1(0.51-2.45)$ & $0.24(0.07-0.78)^{\mathrm{c}}$ & $1.08(0.90-1.29)$ & $0.81(0.69-0.94)^{\mathrm{c}}$ \\
\hline $70-79$ & $0.91(0.80-1.02)$ & $0.26(0.12-0.60)^{\mathrm{c}}$ & $1.00(0.95-1.06)$ & $0.84(0.53-1.34)$ & $1.38(0.97-1.97)$ & $1.16(1.03-1.32)^{\mathrm{c}}$ & $0.87(0.76-0.99)^{\mathrm{c}}$ \\
\hline$\geq 80$ & $1.01(0.87-1.17)$ & $0.62(0.11-3.34)$ & $0.93(0.77-1.12)$ & $0.87(0.37-1.96)$ & $1.13(0.56-2.28)$ & $1.49(1.31-1.69)^{\mathrm{c}}$ & $0.97(0.83-1.15)$ \\
\hline \multicolumn{8}{|l|}{ Sex } \\
\hline Female & $0.84(0.73-0.96)^{\mathrm{c}}$ & $0.22(0.12-0.42)^{\mathrm{c}}$ & $0.88(0.84-0.92)^{\mathrm{c}}$ & $0.59(0.13-2.71)$ & $0.87(0.49-1.53)$ & $1.13(1.02-1.25)^{\mathrm{c}}$ & $0.86(0.76-0.98)^{\mathrm{c}}$ \\
\hline Male & $0.85(0.76-0.95)^{\mathrm{c}}$ & $0.32(0.19-0.53)$ & $0.93(0.90-0.96)^{\mathrm{c}}$ & $0.58(0.25-1.34)$ & $0.61(0.29-1.25)$ & $1.18(1.10-1.28)^{\mathrm{c}}$ & $\begin{array}{l}0.89(0.81- \\
0.98)^{* \mathrm{c}}\end{array}$ \\
\hline \multicolumn{8}{|l|}{ Race } \\
\hline Black & $0.89(0.81-0.98)^{\mathrm{c}}$ & N/A & N/A & N/A & N/A & N/A & $0.89(0.81-0.98)^{\mathrm{c}}$ \\
\hline White & $0.91(0.80-1.03)$ & N/A & N/A & N/A & N/A & N/A & $0.91(0.80-1.03)$ \\
\hline
\end{tabular}

${ }^{\mathrm{a}} \mathrm{RR}$ : relative risk.

${ }^{b}$ N/A: not applicable; no patients reported in specific demographic subgroups for certain countries.

${ }^{\mathrm{c}}$ Statistically significant.

\section{Change in Mean Laboratory Values and Laboratory Testing Rates}

We report standardized mean laboratory values in the first and the second waves at days 0,1 , and 7 since the index date of admission for CRP, ferritin, fibrinogen, procalcitonin, D-dimer, and creatinine in Figure 5. Among all patients, we observed significantly lower mean CRP values throughout the first week of hospitalization on days 0,1 , and 7 in the second wave than in the first wave. All other mean laboratory values on day 0 were not significantly different between the first and second waves. At day 7, we further observed that the mean values of ferritin, fibrinogen, and procalcitonin were all significantly lower in the second wave than in the first wave.

Among patients with severe disease, we observed similar results with regard to comparing mean laboratory values between the first and second waves. Mean CRP values during the first week of hospitalization on days 0,1 , and 7 were significantly lower in the second wave than in the first wave. Mean fibrinogen and procalcitonin values were significantly lower on day 7 in the second wave than in the first wave. 
Figure 5. Standardized mean laboratory values (A) and corresponding laboratory testing rates (B) among all patients and those with severe disease in the first and second waves. Error bars indicate $95 \%$ CIs.
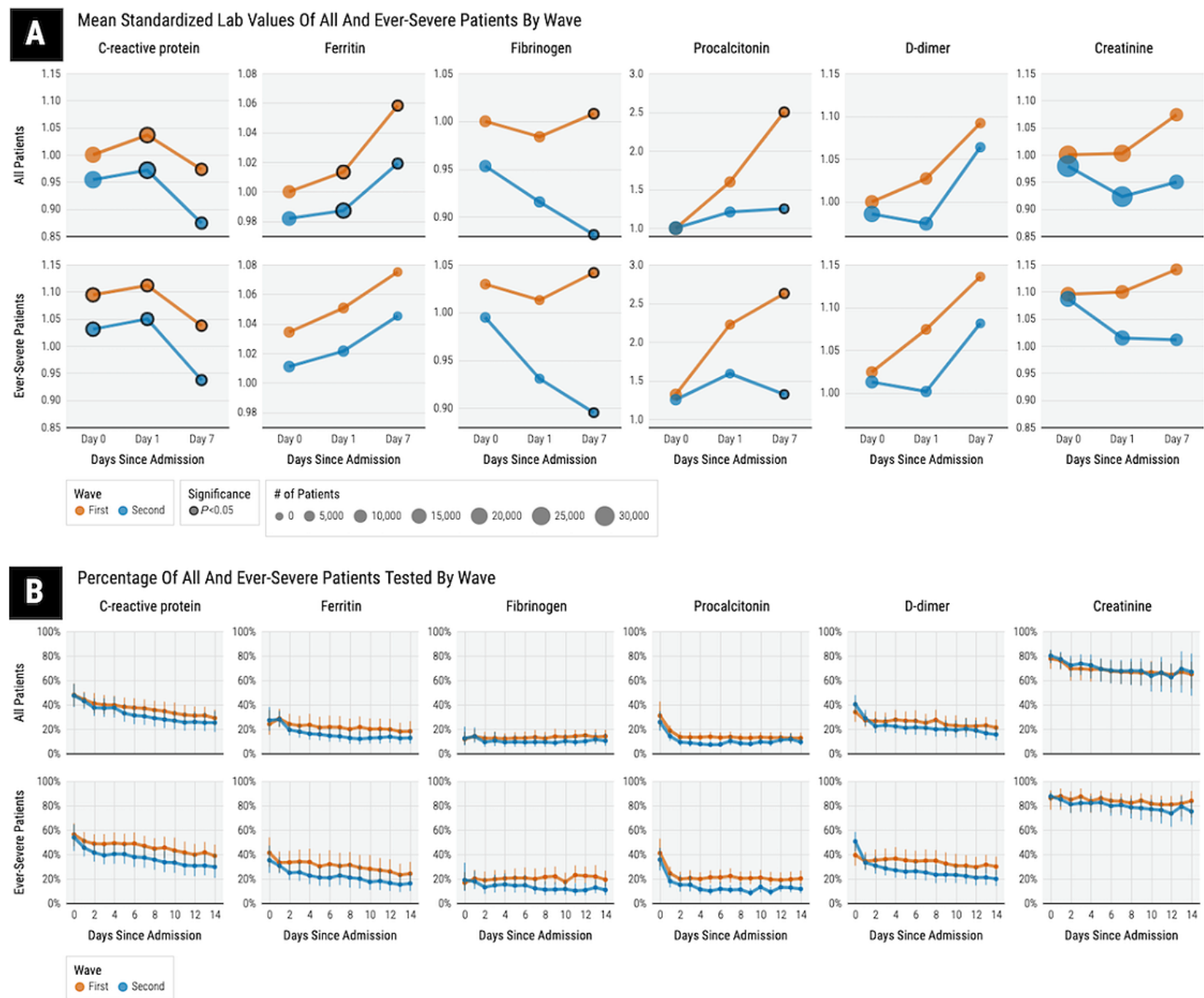

When comparing the overall laboratory testing rates during hospitalization, as reported in Figure 5, we observed that overall testing rates among all patients for procalcitonin were significantly lower across hospitalization days in the second wave than in the first wave. Overall procalcitonin testing rates among patients with severe disease were similarly significantly lower across hospitalization days in the second wave than in the first wave. There were no other significant changes in overall laboratory testing rates. We report laboratory testing rates within each country in Figure 6; creatinine laboratory data were not available from participating health care systems in Germany. Laboratory testing rates among countries varied significantly between the first and second waves. European countries exhibited the most changes in testing rates at admission (day
$0)$. In the second wave, there was a significant increase in the D-dimer testing rate in France, Germany, and Spain, and in the CRP, creatinine, and fibrinogen testing rates in Spain. In Germany, there were significant decreases in the testing rates for CRP, ferritin, and procalcitonin at admission. In Brazil, there was a significant decrease in the testing rate for D-dimer at admission. In contrast, the United States did not have any significant changes in laboratory testing rates at admission. In all countries, except Brazil and Spain, laboratory testing rates in the second wave were generally lower during the second week of hospitalization. In Spain, second hospital week testing rates for CRP, fibrinogen, and creatinine were higher in the second wave than in the first wave. 
Figure 6. Laboratory testing rates across hospitalization days in each country. Error bars indicate 95\% CIs. Laboratory data for creatinine were unavailable for health care systems in Germany. NA: Not Available.

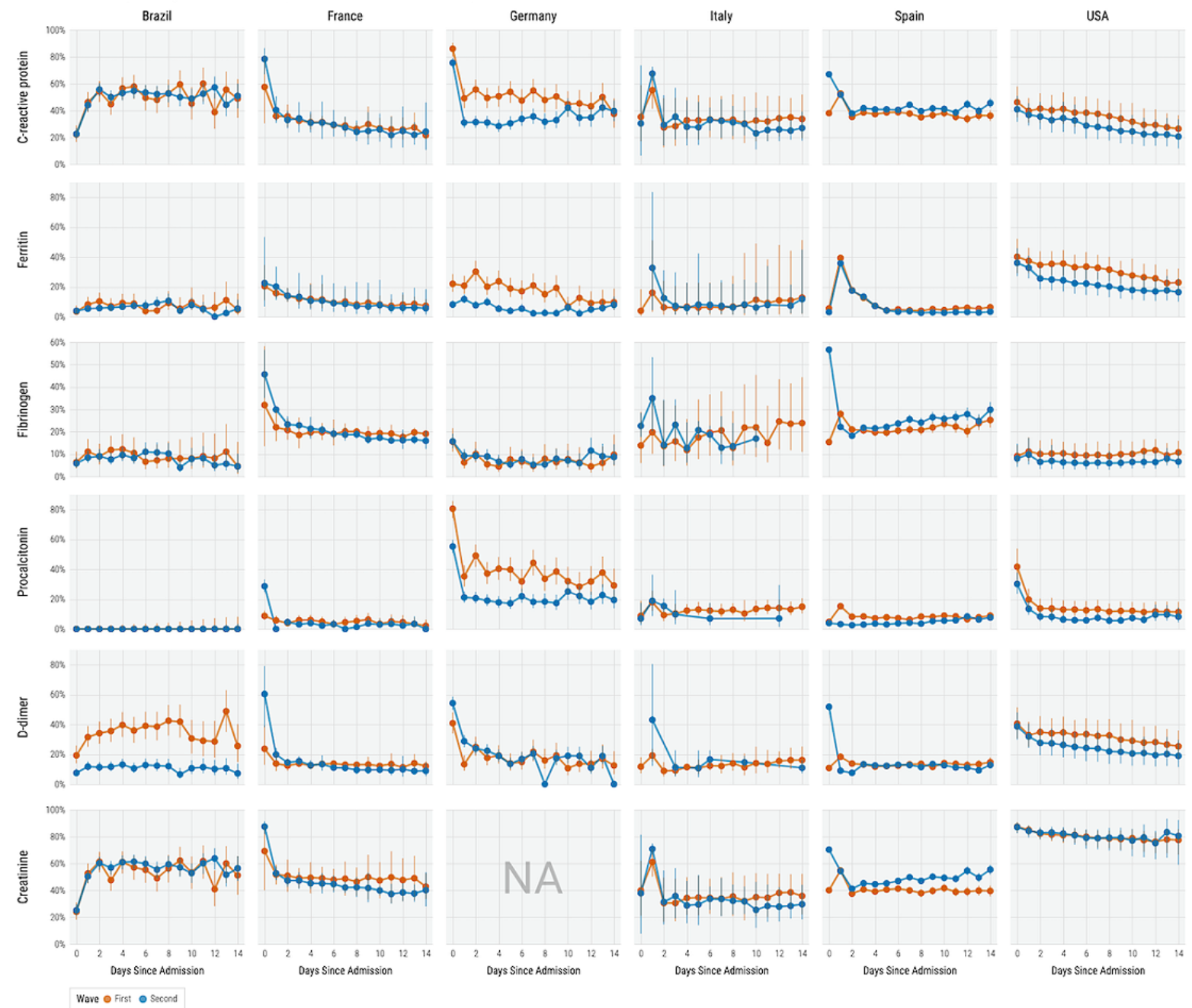

\section{Discussion}

\section{Principal Findings}

In this large EHR-based study, we employed a federated approach to rapidly aggregate and harmonize clinical data across 315 international hospitals from 6 countries that included 79,613 hospitalized patients with SARS-CoV-2 to offer insights on the evolving clinical trajectory of COVID-19 across the first and second waves. We found that patients hospitalized in the second wave were at significantly lower risk for severe COVID-19, corresponding to lower mean laboratory values for several inflammatory markers during the first week of hospitalization in the second wave than in the first wave.

In this study, we capitalized on the availability of real-world EHR data from participating international health care systems within the 4CE to capture pertinent clinical characteristics effectively and accurately. Despite the high heterogeneity in the health systems, we were able to rigorously perform quality checks across all health care centers using a multidisciplinary team approach that engages statisticians, informaticians, and clinicians. Additionally, the multinational nature of our data allowed us to identify country-level variations in temporal trends, as well as distinguish different clinical phenotypes and trajectories in the second wave compared with the first wave of the pandemic.

Notably, our federated approach demonstrated several advantages over methods where hospitals transfer patient-level data to a central repository [30]. By keeping data local within hospitals, we avoided privacy concerns and regulatory barriers that often delay multisite research studies. By comparing the results from different hospitals, rather than treating all the data as a single combined data set, we could identify outliers that suggested data quality problems. Finally, by having local data experts at each site running the database queries, we could leverage their help in addressing these data quality concerns [31,32]. Although more sophisticated analyses, such as machine learning models or robust multivariable models that can adjust for multiple sources of various types of bias, are harder to implement in a federated architecture than in a central repository, this study demonstrated that our federated approach 
enabled us to obtain early clinical insights into the evolving pandemic and helped us gain confidence in the data.

Our data demonstrated a near uniform peak in country-specific hospitalizations in the first wave and a variable peak in country-specific hospitalizations in the second wave, reflecting country-specific patterns in the resurgence of COVID-19-related hospitalizations that were consistent with international tracking sites $[1,9,10]$. In all countries, except Brazil and the United States, the second wave peak was characterized by a lower intensity compared to the first wave peak, possibly reflecting the effects of successful COVID-19 mitigation measures implemented after the first wave $[33,34]$.

Consistent with previous single-country studies, we observed that patients hospitalized in the second wave had an overall lower risk for severe COVID-19 than patients hospitalized in the first wave $[6,12,35,36]$. On further stratifying our analyses by country, we were able to observe that patients in Spain instead had a significantly higher risk for severe disease in the second wave, contrary to what we observed in France and the United States. Although the reasons for the increased risk of severe COVID-19 during Spain's second wave are unclear and likely complex, it is consistent with international tracking sites that indicated increased mortality rates and health care resource use in Spain's second wave, and it reflects the importance of being able to identify country-specific variations in our data [37]. We further note that the data from Spain originated from 1 hospital and were likely subject to some forms of bias. Even when stratifying by demographic subgroups, we observed similar patterns indicating reduced risk for severe COVID-19 in the second wave, particularly among patients aged 26 to 49 and among black patients. However, while the risk of severe disease for the entire population was lower in the second wave for patients aged 26 to 49 , country-specific results demonstrated possible collider bias and small-sample bias in that the individual estimates for Brazil, France, Germany, and Spain were not statistically significant and were imprecise with wide CIs. This is likely due in large part to the smaller sample size of this age group in each country and reflects the need for multicenter studies to improve power. While one might expect to see a less severe disease later in the course of the pandemic due to changes in patient populations over time, improved clinical care, and greater utilization of health care resources compared to the beginning of the pandemic, it is unclear why we did not observe similar relationships for other patient groups. These possible discrepancies are likely due to a variety of different factors, as noted above, as well as sources of bias in our data. Further investigation into these country-specific demographic differences in the change in severe disease risk over the course of the pandemic is warranted and is ongoing in the 4CE.

Our observations comparing laboratory values between the first and second waves support our finding that patients hospitalized during the second wave compared to the first wave had a lower risk for severe disease. We found that mean laboratory values in the second wave exhibited considerable improvement toward typical physiological values compared to the first wave, especially those of inflammatory markers. In particular, the mean values of the positive acute phase reactant CRP were lower across the first week of hospitalization in the second wave than in the first wave, while the mean values of the positive acute phase reactants ferritin, fibrinogen, and procalcitonin were lower at day 7 [38]. This indicates that, on average, patients hospitalized during the second wave may have had less overall systemic inflammation at admission and had improved inflammatory states during the first week of hospitalization in comparison to patients admitted in the first wave [39-41]. Considering that there were no new major effective pharmacologic therapies for patients with COVID-19 introduced between the first and second waves, these general patterns may be reflective of a less vulnerable patient population in the second wave, as well as improved general clinical management strategies of COVID-19 in the second wave [42-50]. Ongoing $4 \mathrm{CE}$ analyses are further investigating these findings.

We further observed variations in laboratory testing rates among countries between the first and second waves. These changes in laboratory testing rates at admission may be reflective of greater understanding of COVID-19 pathophysiology and clinical trajectories leading to changes in clinical protocols. For example, there was a significant increase in the testing rate of D-dimer at admission in France, Germany, and Spain in the second wave. This particular change in clinical practice may have been driven in part by the growing literature supporting the association of high D-dimer values with worse outcomes in COVID-19 and the possibility of using D-dimer to clinically classify and evaluate the prognosis of COVID-19 patients [51-55]. Further, although there were no significant changes in laboratory testing at admission in the United States, we observed that testing rates across hospitalization days were generally higher than in other European countries regardless of wave. Future investigations are warranted to infer why we observed these patterns.

\section{Study Limitations}

We acknowledge several limitations for this EHR-based observational cohort study. This study was limited to patients who were admitted to a hospital, either because they experienced more severe illness or because they had other possibly biasing conditions; as with many EHR-based studies, we were unable to ascertain the precise reasons for admission. Similar to other EHR-based studies, we were not able to validate if patients were hospitalized due to COVID-19 or happened to have a positive test when admitted for an unrelated medical condition. Thus, we could not completely mitigate selection bias or misclassification bias in our cohort identification. Due to the limited scope of the extracted aggregate data, we could not effectively control for patient-level potentially confounding variables such as comorbidities, medication use (both prior to and during hospitalization), and other societal and environmental factors, all of which can induce many types of biases [56]. Data pertaining to certain countries, most notably Brazil and Germany, may have been subject to small sample bias. Furthermore, mean laboratory values at later days of hospitalization were subject to censoring (transfer, discharge, and death) and thus dropout bias, so we could not effectively compare mean laboratory values within a single wave at different timepoints. However, we believe that facilitating comparisons at identical timepoints between different waves is not subject to as much dropout bias. In an effort to provide 
information regarding the nature of censoring that existed in the data, we report in Multimedia Appendix 3 the proportion of patients who were alive and remained in the hospital across hospitalization days for each country by wave. Further, considering the aforementioned limitations, we took special caution to make conclusions that were mostly descriptive in nature. In the future, we hope to disaggregate EHR data to the patient level in order to adjust for many of these biases, if possible, under institutional review board approval.

\section{Conclusions}

For assessing the evolving epidemiology, pathophysiology, and health care dynamics of the COVID-19 pandemic, we leveraged
EHR data in a large international cohort of hospitalized patients with SARS-CoV-2 to rapidly characterize the clinical course of patients admitted to hospital during the first 2 major waves of the pandemic. We were able to characterize changes in hospitalization rates, demographic characteristics, severity risk, and mean laboratory values using data from 79,613 patients across 315 health care systems in 6 countries. Our study's federated approach demonstrates the feasibility and power of leveraging real-world EHR data from multiple countries to support our understanding of evolving pandemics such as COVID-19.

\section{Acknowledgments}

GMW is supported by National Institutes of Health (NIH)/National Center for Advancing Translational Sciences (NCATS) UL1TR002541 and UL1TR000005, NIH/National Library of Medicine (NLM) R01LM013345, and NIH/National Human Genome Research Institute (NHGRI) 3U01HG008685-05S2. NG is supported by NIH/NLM T15LM007092. DAH is supported by NCATS UL1TR002240. RK is supported by Clinical and Translational Science Awards (CTSA) Award UL1TR001998. KK is supported by NIH/NCATS UL1TR001450. DLM is supported by NIH/NCATS UL1TR001878. SNM is supported by NIH/NCATS 5UL1TR001857-05 and NIH/NHGRI 5R01HG009174-04. GSO is supported by NIH P30ES017885 and U24CA210967. LPP is supported by CTSA Award UL1TR002366. JS is supported by NIH/NCATS UL1TR001881. SV is supported by NIH/NLM R01LM012095 and NIH/NCATS UL1TR001857. ZX is supported by National Institute of Neurological Disorders and Stroke (NINDS) R01NS098023. AMS is supported by NIH/National Heart, Lung, and Blood Institute (NHLBI) K23HL148394, L40HL148910, and NIH/NCATS UL1TR001420.

\section{Authors' Contributions}

All authors made contributions to conception and design; acquisition, analysis, and interpretation of data; drafting the article or revising it critically for important intellectual content; and final approval of the version to be published. The Consortium for Clinical Characterization of COVID-19 by EHR (4CE) consists of: James R Aaron, Giuseppe Agapito, Adem Albayrak, Mario Alessiani, Anna Alloni, Danilo F Amendola, Li LLJ Anthony, Bruce J Aronow, Fatima Ashraf, Andrew Atz, Paul Avillach, Paula S Azevedo, James Balshi, Brett K Beaulieu-Jones, Douglas S Bell, Antonio Bellasi, Riccardo Bellazzi, Vincent Benoit, Michele Beraghi, José Luis Bernal Sobrino, Mélodie Bernaux, Romain Bey, Alvar Blanco Martínez, Martin Boeker, Clara-Lea Bonzel, John Booth, Silvano Bosari, Florence T Bourgeois, Robert L Bradford, Gabriel A Brat, Stéphane Bréant, Carlos Tadeu Breda Neto, Nicholas W Brown, William A Bryant, Mauro Bucalo, Anita Burgun, Tianxi Cai, Mario Cannataro, Aldo Carmona, Charlotte Caucheteux, Julien Champ, Jin Chen, Krista Chen, Luca Chiovato, Lorenzo Chiudinelli, Kelly Cho, James J Cimino, Tiago K Colicchio, Sylvie Cormont, Sébastien Cossin, Jean B Craig, Juan Luis Cruz Bermúdez, Jaime Cruz Rojo, Arianna Dagliati, Mohamad Daniar, Christel Daniel, Priyam Das, Anahita Davoudi, Batsal Devkota, Julien Dubiel, Loic Esteve, Hossein Estiri, Shirley Fan, Robert W Follett, Thomas Ganslandt, Noelia García Barrio, Lana X Garmire, Nils Gehlenborg, Alon Geva, Tobias Gradinger, Alexandre Gramfort, Romain Griffier, Nicolas Griffon, Olivier Grisel, Alba Gutiérrez-Sacristán, David A Hanauer, Christian Haverkamp, Bing He, Darren W Henderson, Martin Hilka, Yuk-Lam Ho, John H Holmes, Chuan Hong, Petar Horki, Kenneth M Huling, Meghan R Hutch, Richard W Issitt, Anne Sophie Jannot, Vianney Jouhet, Mark S Keller, Chris J Kennedy, Katie Kirchoff, Jeffrey G Klann, Isaac S Kohane, Ian D Krantz, Detlef Kraska, Ashok K Krishnamurthy, Sehi L'Yi, Trang T Le, Judith Leblanc, Andressa RR Leite, Guillaume Lemaitre, Leslie Lenert, Damien Leprovost, Molei Liu, Ne Hooi Will Loh, Qi Long, Sara Lozano-Zahonero, Yuan Luo, Kristine E Lynch, Sadiqa Mahmood, Sarah Maidlow, Adeline Makoudjou, Alberto Malovini, Kenneth D Mandl, Chengsheng Mao, Anupama Maram, Patricia Martel, Marcelo R Martins, Aaron J Masino, Maria Mazzitelli, Arthur Mensch, Marianna Milano, Marcos F Minicucci, Bertrand Moal, Jason H Moore, Cinta Moraleda, Jeffrey S Morris, Michele Morris, Karyn L Moshal, Sajad Mousavi, Danielle L Mowery, Douglas A Murad, Shawn N Murphy, Thomas P Naughton, Antoine Neuraz, Kee Yuan Ngiam, Wanjiku FM Njoroge, James B Norman, Jihad Obeid, Marina P Okoshi, Karen L Olson, Gilbert S Omenn, Nina Orlova, Brian D Ostasiewski, Nathan P Palmer, Nicolas Paris, Lav P Patel, Miguel Pedrera Jimenez, Emily R Pfaff, Danielle Pillion, Hans U Prokosch, Robson A Prudente, Víctor Quirós González, Rachel B Ramoni, Maryna Raskin, Siegbert Rieg, Gustavo Roig Domínguez, Pablo Rojo, Carlos Sáez, Elisa Salamanca, Malarkodi J Samayamuthu, L Nelson Sanchez-Pinto, Arnaud Sandrin, Nandhini Santhanam, Janaina CC Santos, Javier W Sanz, Maria Savino, Emily R Schriver, Petra Schubert, Juergen Schuettler, Luigia Scudeller, Neil J Sebire, Pablo Serrano Balazote, Patricia Serre, Arnaud Serret-Larmande, Zahra Shakeri, Domenick Silvio, Piotr Sliz, Jiyeon Son, Charles Sonday, Andrew M South, Anastasia Spiridou, Amelia LM Tan, Bryce WQ Tan, Byorn WL Tan, Suzana E Tanni, Deanne M Taylor, Ana I Terriza Torres, Valentina Tibollo, Patric Tippmann, Carlo Torti, Enrico M Trecarichi, Yi-Ju Tseng, Andrew K Vallejos, Gael Varoquaux, Margaret E Vella, Guillaume Verdy, Jill-Jênn Vie, Shyam Visweswaran, Michele Vitacca, Kavishwar B Wagholikar, Lemuel R Waitman, Xuan 
Wang, Demian Wassermann, Griffin M Weber, Zongqi Xia, Xin Xiong, Nadir Yehya, William Yuan, Alberto Zambelli, Harrison G Zhang, Daniel Zoeller, and Chiara Zucco.

These authors contributed equally: GMW, HGZ, SL. These authors jointly supervised the work: TC, AMS, GAB.

\section{Conflicts of Interest}

None declared.

\section{Multimedia Appendix 1}

Descriptions of CSV files generated at participating health care systems.

[DOCX File, 13 KB-Multimedia Appendix 1]

\section{Multimedia Appendix 2}

Prevalence of demographic subgroups in the first and second waves for the entire cohort and by country, and estimated absolute risk for severe COVID-19 by demographic subgroups inclusive of 5 Veterans Affairs health care systems. Error bars indicate 95\% CIs. *Significant difference by nonoverlapping 95\% CIs.

[PNG File, 297 KB-Multimedia Appendix 2]

\section{Multimedia Appendix 3}

Proportion of patients who were alive and still in the hospital across hospitalization days.

[PNG File, 199 KB-Multimedia Appendix 3]

\section{References}

1. COVID-19 Map - Johns Hopkins Coronavirus Resource Center. URL: https://coronavirus.jhu.edu/map.html [accessed 2021-05-03]

2. Devi S. COVID-19 resurgence in Iran. The Lancet 2020 Jun 20;395(10241):1896 [FREE Full text] [doi: 10.1016/S0140-6736(20)31407-0] [Medline: 32563363]

3. Looi M. Covid-19: Is a second wave hitting Europe? BMJ 2020 Oct 28;371:m4113. [doi: 10.1136/bmj.m4113] [Medline: 33115704]

4. Shimizu K, Wharton G, Sakamoto H, Mossialos E. Resurgence of covid-19 in Japan. BMJ 2020 Aug 18;370:m3221. [doi: 10.1136/bmj.m3221] [Medline: 32816821]

5. Sabino EC, Buss LF, Carvalho MPS, Prete CA, Crispim MAE, Fraiji NA, et al. Resurgence of COVID-19 in Manaus, Brazil, despite high seroprevalence. The Lancet 2021 Feb 06;397(10273):452-455 [FREE Full text] [doi: 10.1016/S0140-6736(21)00183-5] [Medline: 33515491]

6. Saito S, Asai Y, Matsunaga N, Hayakawa K, Terada M, Ohtsu H, et al. First and second COVID-19 waves in Japan: A comparison of disease severity and characteristics. J Infect 2021 Apr;82(4):84-123 [FREE Full text] [doi:

10.1016/j.jinf.2020.10.033] [Medline: 33152376]

7. Win A. Rapid rise of COVID-19 second wave in Myanmar and implications for the Western Pacific region. QJM 2020 Dec 01;113(12):856-857 [FREE Full text] [doi: 10.1093/qjmed/hcaa290] [Medline: 33095232]

8. Vahidy FS, Drews AL, Masud FN, Schwartz RL, Askary BB, Boom ML, et al. Characteristics and Outcomes of COVID-19 Patients During Initial Peak and Resurgence in the Houston Metropolitan Area. JAMA 2020 Sep 08;324(10):998-1000 [FREE Full text] [doi: 10.1001/jama.2020.15301] [Medline: 32789492]

9. Cumulative deaths. IHME COVID-19 Projections. URL: https://covid19.healthdata.org/ united-states-of-america?view=cumulative-deaths\&tab=trend [accessed 2021-06-17]

10. Coronavirus (COVID-19) Deaths. Our World in Data. URL: https://ourworldindata.org/covid-deaths [accessed 2021-06-17]

11. Mollinedo-Gajate I, Villar-Álvarez F, Zambrano-Chacón M, Núñez-García L, de la Dueña-Muñoz L, López-Chang C, et al. First and Second Waves of Coronavirus Disease 2019 in Madrid, Spain: Clinical Characteristics and Hematological Risk Factors Associated With Critical/Fatal Illness. Crit Care Explor 2021 Feb;3(2):e0346 [FREE Full text] [doi: 10.1097/CCE.0000000000000346] [Medline: 33634266]

12. Contou D, Fraissé M, Pajot O, Tirolien J, Mentec H, Plantefève G. Comparison between first and second wave among critically ill COVID-19 patients admitted to a French ICU: no prognostic improvement during the second wave? Crit Care 2021 Jan 04;25(1):3 [FREE Full text] [doi: 10.1186/s13054-020-03449-6] [Medline: 33397421]

13. Long SW, Olsen RJ, Christensen PA, Bernard DW, Davis JJ, Shukla M, et al. Molecular Architecture of Early Dissemination and Massive Second Wave of the SARS-CoV-2 Virus in a Major Metropolitan Area. mBio 2020 Oct 30;11(6):e02707-e02720 [FREE Full text] [doi: 10.1128/mBio.02707-20] [Medline: $\underline{33127862]}$

14. Brat GA, Weber GM, Gehlenborg N, Avillach P, Palmer NP, Chiovato L, et al. International electronic health record-derived COVID-19 clinical course profiles: the 4CE consortium. NPJ Digit Med 2020;3:109 [FREE Full text] [doi: 10.1038/s41746-020-00308-0] [Medline: 32864472] 
15. Weber GM, Hong C, Palmer NP, Avillach P, Murphy SN, Gutiérrez-Sacristán A, Consortium for Clinical Characterization of COVID-19 by EHR (4CE), et al. International Comparisons of Harmonized Laboratory Value Trajectories to Predict Severe COVID-19: Leveraging the 4CE Collaborative Across 342 Hospitals and 6 Countries: A Retrospective Cohort Study. medRxiv 2021 Feb 05 [FREE Full text] [doi: 10.1101/2020.12.16.20247684] [Medline: 33564777]

16. Jones AL, Pettey WBP, Carter ME, Brignone E, Redd A, Suo Y, et al. Regional Variations in Documentation of Sexual Trauma Concepts in Electronic Medical Records in the United States Veterans Health Administration. AMIA Annu Symp Proc 2019;2019:514-522 [FREE Full text] [Medline: 32308845]

17. Le TT, Gutiérrez-Sacristán A, Son J, Hong C, South AM, Beaulieu-Jones BK, et al. Multinational Prevalence of Neurological Phenotypes in Patients Hospitalized with COVID-19. medRxiv 2021 Jan 29 [FREE Full text] [doi: 10.1101/2021.01.27.21249817] [Medline: 33655281]

18. Klann JG, Estiri H, Weber GM, Moal B, Avillach P, Hong C, Consortium for Clinical Characterization of COVID-19 by EHR (4CE) (CONSORTIA AUTHOR), et al. Validation of an internationally derived patient severity phenotype to support COVID-19 analytics from electronic health record data. J Am Med Inform Assoc 2021 Jul 14;28(7):1411-1420 [FREE Full text] [doi: 10.1093/jamia/ocab018] [Medline: 33566082]

19. DerSimonian R, Laird N. Meta-analysis in clinical trials. Control Clin Trials 1986 Sep;7(3):177-188. [doi: 10.1016/0197-2456(86)90046-2] [Medline: 3802833]

20. National Center for Veterans Analysis and Statistics. United States Department of Veterans Affairs. URL: https://www. va.gov/vetdata/veteran population.asp [accessed 2021-06-07]

21. Huang I, Pranata R, Lim MA, Oehadian A, Alisjahbana B. C-reactive protein, procalcitonin, D-dimer, and ferritin in severe coronavirus disease-2019: a meta-analysis. Ther Adv Respir Dis 2020;14:1753466620937175 [FREE Full text] [doi: 10.1177/1753466620937175] [Medline: $\underline{32615866]}$

22. Carubbi F, Salvati L, Alunno A, Maggi F, Borghi E, Mariani R, et al. Ferritin is associated with the severity of lung involvement but not with worse prognosis in patients with COVID-19: data from two Italian COVID-19 units. Sci Rep 2021 Mar 01;11(1):4863 [FREE Full text] [doi: 10.1038/s41598-021-83831-8] [Medline: $\underline{33649408]}$

23. Huang C, Wang Y, Li X, Ren L, Zhao J, Hu Y, et al. Clinical features of patients infected with 2019 novel coronavirus in Wuhan, China. The Lancet 2020 Feb 15;395(10223):497-506 [FREE Full text] [doi: 10.1016/S0140-6736(20)30183-5] [Medline: $\underline{31986264]}$

24. Smilowitz NR, Kunichoff D, Garshick M, Shah B, Pillinger M, Hochman JS, et al. C-reactive protein and clinical outcomes in patients with COVID-19. Eur Heart J 2021 Jun 14;42(23):2270-2279 [FREE Full text] [doi: 10.1093/eurheartj/ehaa1103] [Medline: 33448289]

25. Shi S, Nie B, Chen X, Cai Q, Lin C, Zhao G, et al. Clinical and laboratory characteristics of severe and non-severe patients with COVID-19: A retrospective cohort study in China. J Clin Lab Anal 2021 Jan;35(1):e23692 [FREE Full text] [doi: 10.1002/jcla.23692] [Medline: 33389777]

26. Bi X, Su Z, Yan H, Du J, Wang J, Chen L, et al. Prediction of severe illness due to COVID-19 based on an analysis of initial Fibrinogen to Albumin Ratio and Platelet count. Platelets 2020 Jul 03;31(5):674-679 [FREE Full text] [doi: 10.1080/09537104.2020.1760230] [Medline: $\underline{\text { 32367765] }}$

27. Statsenko Y, Al Zahmi F, Habuza T, Gorkom KN, Zaki N. Prediction of COVID-19 severity using laboratory findings on admission: informative values, thresholds, ML model performance. BMJ Open 2021 Feb 26;11(2):e044500 [FREE Full text] [doi: 10.1136/bmjopen-2020-044500] [Medline: $\underline{33637550}$ ]

28. Wang F, Hou H, Wang T, Luo Y, Tang G, Wu S, et al. Establishing a model for predicting the outcome of COVID-19 based on combination of laboratory tests. Travel Med Infect Dis 2020;36:101782 [FREE Full text] [doi: 10.1016/j.tmaid.2020.101782] [Medline: 32526372]

29. Consortium for Clinical Characterization of COVID-19 by EHR. URL: https://covidclinical.net/ [accessed 2021-09-23]

30. Haendel MA, Chute CG, Bennett TD, Eichmann DA, Guinney J, Kibbe WA, N3C Consortium. The National COVID Cohort Collaborative (N3C): Rationale, design, infrastructure, and deployment. J Am Med Inform Assoc 2021 Mar 01;28(3):427-443 [FREE Full text] [doi: 10.1093/jamia/ocaa196] [Medline: 32805036]

31. Wallace S, Myles PS. Solving the challenges of large multicenter trials in anesthesia. HSR Proc Intensive Care Cardiovasc Anesth 2009;1(3):46-53 [FREE Full text] [Medline: 23439979]

32. de Jonge JC, Reinink H, Colam B, Alpers I, Ciccone A, Csiba L, et al. Regulatory delays in a multinational clinical stroke trial. Eur Stroke J 2021 Jun 30;6(2):120-127 [FREE Full text] [doi: 10.1177/23969873211004845] [Medline: $\underline{34414286}$ ]

33. Haug N, Geyrhofer L, Londei A, Dervic E, Desvars-Larrive A, Loreto V, et al. Ranking the effectiveness of worldwide COVID-19 government interventions. Nat Hum Behav 2020 Dec;4(12):1303-1312. [doi: 10.1038/s41562-020-01009-0] [Medline: $\underline{33199859]}$

34. Tam K, Walker N, Moreno J. Effect of mitigation measures on the spreading of COVID-19 in hard-hit states in the U.S. PLoS One 2020;15(11):e0240877 [FREE Full text] [doi: 10.1371/journal.pone.0240877] [Medline: 33141823]

35. Docherty AB, Mulholland RH, Lone NI, Cheyne CP, De Angelis D, Diaz-Ordaz K, et al. Changes in in-hospital mortality in the first wave of COVID-19: a multicentre prospective observational cohort study using the WHO Clinical Characterisation Protocol UK. The Lancet Respiratory Medicine 2021 Jul 14;9(7):773-785 [FREE Full text] [doi: 10.1016/S2213-2600(21)00175-2] [Medline: 34000238] 
36. Karagiannidis C, Windisch W, McAuley DF, Welte T, Busse R. Major differences in ICU admissions during the first and second COVID-19 wave in Germany. The Lancet Respiratory Medicine 2021 May;9(5):e47-e48 [FREE Full text] [doi: 10.1016/S2213-2600(21)00101-6] [Medline: 33684356]

37. Daily infections and testing. IHME COVID-19 Projections. URL: https://covid19.healthdata.org/ spain?view=infections-testing\&tab=trend\&test=infections [accessed 2021-06-17]

38. Gulhar R, Ashraf M, Jialal I. Physiology, Acute Phase Reactants. In: StatPearls [Internet]. Treasure Island, FL: StatPearls Publishing; 2021.

39. Nehring SM, Goyal A, Bansal P, Patel BC. C Reactive Protein. In: StatPearls [Internet]. Treasure Island, FL: StatPearls Publishing; 2021.

40. Knovich MA, Storey JA, Coffman LG, Torti SV, Torti FM. Ferritin for the clinician. Blood Rev 2009 May;23(3):95-104 [FREE Full text] [doi: 10.1016/j.blre.2008.08.001] [Medline: 18835072 ]

41. Kell DB, Pretorius E. Serum ferritin is an important inflammatory disease marker, as it is mainly a leakage product from damaged cells. Metallomics 2014 Apr;6(4):748-773. [doi: 10.1039/c3mt00347g] [Medline: 24549403]

42. Sanders JM, Monogue ML, Jodlowski TZ, Cutrell JB. Pharmacologic Treatments for Coronavirus Disease 2019 (COVID-19): A Review. JAMA 2020 May 12;323(18):1824-1836. [doi: 10.1001/jama.2020.6019] [Medline: 32282022]

43. Sheahan TP, Sims AC, Leist SR, Schäfer A, Won J, Brown AJ, et al. Comparative therapeutic efficacy of remdesivir and combination lopinavir, ritonavir, and interferon beta against MERS-CoV. Nat Commun 2020 Jan 10;11(1):222 [FREE Full text] [doi: 10.1038/s41467-019-13940-6] [Medline: $\underline{\text { 31924756] }}$

44. Gautret P, Lagier J, Parola P, Hoang VT, Meddeb L, Mailhe M, et al. Hydroxychloroquine and azithromycin as a treatment of COVID-19: results of an open-label non-randomized clinical trial. International Journal of Antimicrobial Agents 2020 Jul;56(1):105949 [FREE Full text] [doi: 10.1016/j.ijantimicag.2020.105949] [Medline: $\underline{32205204]}$

45. Spinner CD, Gottlieb RL, Criner GJ, Arribas López JR, Cattelan AM, Soriano Viladomiu A, GS-US-540-5774 Investigators. Effect of Remdesivir vs Standard Care on Clinical Status at 11 Days in Patients With Moderate COVID-19: A Randomized Clinical Trial. JAMA 2020 Sep 15;324(11):1048-1057 [FREE Full text] [doi: 10.1001/jama.2020.16349] [Medline: 32821939]

46. Wang Y, Zhang D, Du G, Du R, Zhao J, Jin Y, et al. Remdesivir in adults with severe COVID-19: a randomised, double-blind, placebo-controlled, multicentre trial. The Lancet 2020 May 16;395(10236):1569-1578 [FREE Full text] [doi: 10.1016/S0140-6736(20)31022-9] [Medline: 32423584]

47. Boulware DR, Pullen MF, Bangdiwala AS, Pastick KA, Lofgren SM, Okafor EC, et al. A Randomized Trial of Hydroxychloroquine as Postexposure Prophylaxis for Covid-19. N Engl J Med 2020 Aug 06;383(6):517-525 [FREE Full text] [doi: 10.1056/NEJMoa2016638] [Medline: 32492293]

48. Mitjà $\mathrm{O}$, Corbacho-Monné M, Ubals M, Alemany A, Suñer C, Tebé C, BCN-PEP-CoV2 Research Group. A Cluster-Randomized Trial of Hydroxychloroquine for Prevention of Covid-19. N Engl J Med 2021 Feb 04;384(5):417-427 [FREE Full text] [doi: 10.1056/NEJMoa2021801] [Medline: 33289973]

49. Self WH, Semler MW, Leither LM, Casey JD, Angus DC, Brower RG, National Heart, Lung, Blood Institute PETAL Clinical Trials Network, et al. Effect of Hydroxychloroquine on Clinical Status at 14 Days in Hospitalized Patients With COVID-19: A Randomized Clinical Trial. JAMA 2020 Dec 01;324(21):2165-2176 [FREE Full text] [doi: 10.1001/jama.2020.22240] [Medline: $\underline{33165621}$ ]

50. WHO Solidarity Trial Consortium, Pan H, Peto R, Henao-Restrepo A, Preziosi M, Sathiyamoorthy V, et al. Repurposed Antiviral Drugs for Covid-19 - Interim WHO Solidarity Trial Results. N Engl J Med 2021 Feb 11;384(6):497-511 [FREE Full text] [doi: 10.1056/NEJMoa2023184] [Medline: $\underline{\text { 33264556] }}$

51. Yao Y, Cao J, Wang Q, Shi Q, Liu K, Luo Z, et al. D-dimer as a biomarker for disease severity and mortality in COVID-19 patients: a case control study. J Intensive Care 2020;8:49 [FREE Full text] [doi: 10.1186/s40560-020-00466-Z] [Medline: $\underline{32665858}]$

52. Düz ME, Balcı A, Menekşe E. D-dimer levels and COVID-19 severity: Systematic Review and Meta-Analysis. Tuberk Toraks 2020 Dec;68(4):353-360 [FREE Full text] [doi: 10.5578/tt.70351] [Medline: 33448732]

53. Yu H, Qin C, Chen M, Wang W, Tian D. D-dimer level is associated with the severity of COVID-19. Thromb Res 2020 Nov;195:219-225 [FREE Full text] [doi: 10.1016/j.thromres.2020.07.047] [Medline: $\underline{32777639]}$

54. Berger JS, Kunichoff D, Adhikari S, Ahuja T, Amoroso N, Aphinyanaphongs Y, et al. Prevalence and Outcomes of D-Dimer Elevation in Hospitalized Patients With COVID-19. Arterioscler Thromb Vasc Biol 2020 Oct;40(10):2539-2547 [FREE Full text] [doi: 10.1161/ATVBAHA.120.314872] [Medline: 32840379]

55. He X, Yao F, Chen J, Wang Y, Fang X, Lin X, et al. The poor prognosis and influencing factors of high D-dimer levels for COVID-19 patients. Sci Rep 2021 Jan 19;11(1):1830 [FREE Full text] [doi: 10.1038/s41598-021-81300-w] [Medline: 33469072]

56. Cohen JB, D'Agostino McGowan L, Jensen ET, Rigdon J, South AM. Evaluating sources of bias in observational studies of angiotensin-converting enzyme inhibitor/angiotensin II receptor blocker use during COVID-19: beyond confounding. J Hypertens 2021 Apr 01;39(4):795-805 [FREE Full text] [doi: 10.1097/HJH.0000000000002706] [Medline: 33186321] 


\author{
Abbreviations \\ 4CE: Consortium for Clinical Characterization of COVID-19 by EHR \\ CRP: C-reactive protein \\ EHR: electronic health record \\ ICD: International Classification of Diseases \\ RR: relative risk \\ VA: Veterans Affairs
}

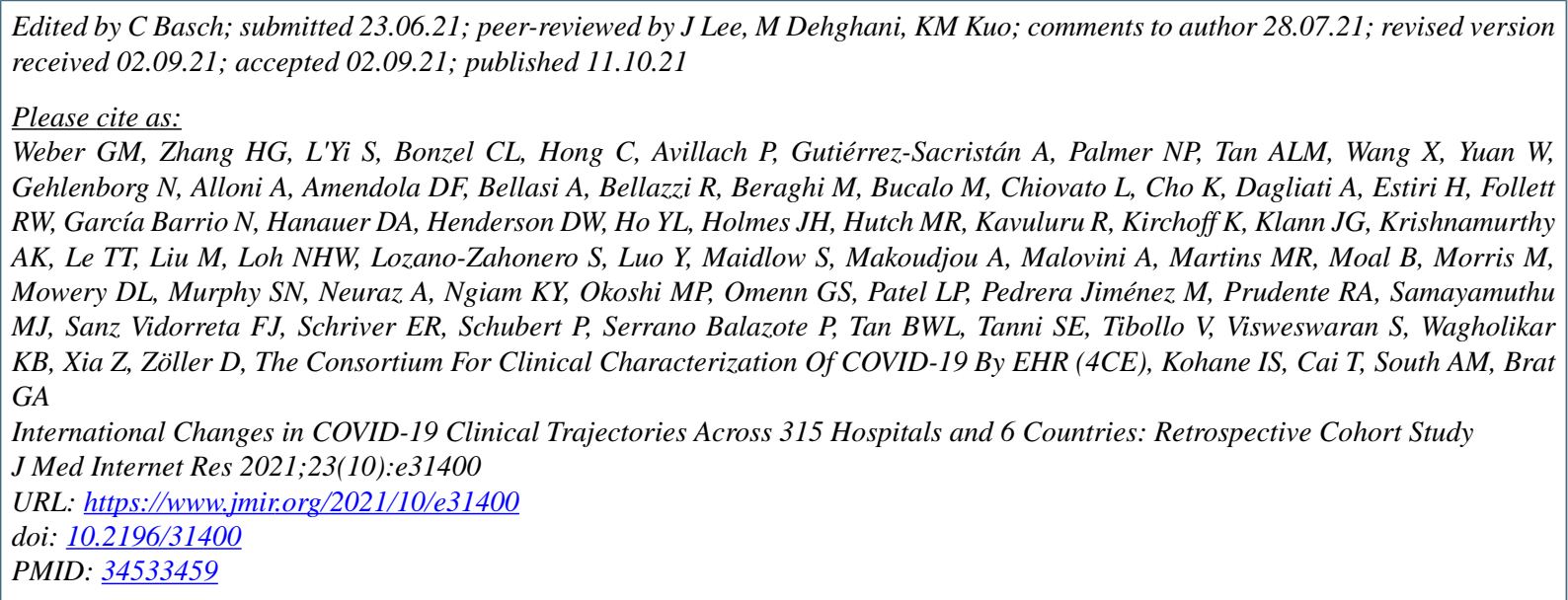

(C) Griffin M Weber, Harrison G Zhang, Sehi L'Yi, Clara-Lea Bonzel, Chuan Hong, Paul Avillach, Alba Gutiérrez-Sacristán, Nathan P Palmer, Amelia Li Min Tan, Xuan Wang, William Yuan, Nils Gehlenborg, Anna Alloni, Danilo F Amendola, Antonio Bellasi, Riccardo Bellazzi, Michele Beraghi, Mauro Bucalo, Luca Chiovato, Kelly Cho, Arianna Dagliati, Hossein Estiri, Robert W Follett, Noelia García Barrio, David A Hanauer, Darren W Henderson, Yuk-Lam Ho, John H Holmes, Meghan R Hutch, Ramakanth Kavuluru, Katie Kirchoff, Jeffrey G Klann, Ashok K Krishnamurthy, Trang T Le, Molei Liu, Ne Hooi Will Loh, Sara Lozano-Zahonero, Yuan Luo, Sarah Maidlow, Adeline Makoudjou, Alberto Malovini, Marcelo Roberto Martins, Bertrand Moal, Michele Morris, Danielle L Mowery, Shawn N Murphy, Antoine Neuraz, Kee Yuan Ngiam, Marina P Okoshi, Gilbert S Omenn, Lav P Patel, Miguel Pedrera Jiménez, Robson A Prudente, Malarkodi Jebathilagam Samayamuthu, Fernando J Sanz Vidorreta, Emily R Schriver, Petra Schubert, Pablo Serrano Balazote, Byorn WL Tan, Suzana E Tanni, Valentina Tibollo, Shyam Visweswaran, Kavishwar B Wagholikar, Zongqi Xia, Daniela Zöller, The Consortium For Clinical Characterization Of COVID-19 By EHR (4CE), Isaac S Kohane, Tianxi Cai, Andrew M South, Gabriel A Brat. Originally published in the Journal of Medical Internet Research (https://www.jmir.org), 11.10.2021. This is an open-access article distributed under the terms of the Creative Commons Attribution License (https://creativecommons.org/licenses/by/4.0/), which permits unrestricted use, distribution, and reproduction in any medium, provided the original work, first published in the Journal of Medical Internet Research, is properly cited. The complete bibliographic information, a link to the original publication on https://www.jmir.org/, as well as this copyright and license information must be included. 